\title{
MONGOL CLOTHING IN THE YUAN PERIOD*
}

\author{
ILDIKÓ OKA
}

\author{
Department of Mongol and Inner Asian Studies, Eötvös Loránd University \\ H-1088 Budapest, Múzeum krt. 4/b, Hungary \\ e-mail: okaildiko@yahoo.com
}

The subject of this paper is clothing, specifically the costumes of the Great Mongol Empire. It is based on recent archaeological discoveries from the territory of the Yuan and the Juchid realms, and in particular on my personal study of the textile finds from Nartiin Xad and Buxiin Xušuu, Mongolia. The reconstruction of some of the costumes from there have made it possible to have a more complete picture of the clothes and to recognise their parallels not only among the other archaeological finds, but also as regards the figural representations of the era. The data of these costumes together with the written sources provide us a new way of understanding the clothing culture of the Mongol imperial era.

Key words: archaeological textiles, clothing, costumes, Mongol, Yuan, Ilkhanid, Golden Horde, Chronicon Pictum.

\section{Introduction}

Thomas T. Allsen in his monograph has written about the connection of clothes and political cultures of the Mongol Empire and suggested that his historical studies should be continued by "specialists on textiles" (Allsen 2001, p. 10). This paper tries to focus on the costumes of the empire and to define the characteristic features that made them "Mongol" in the eyes of the contemporaries. To make this problem even more complicated, similar costumes, worn by non-Mongol people, appear in the figural representations from outside the Mongol Empire. The meaning of these clothes must have been different there; but even the Great Mongol Empire contained a diverse

* The archaeological textile material is the subject of a joint research of Ulambayaryn Erdenbat (Archaeological Institute, Mongolian Academy of Science), Bayarsaikhan Jamsranjav (Mongolian National Museum) and Ildikó Hajnalka Oka (ELTE University, Budapest). 
population and the Mongol army itself consisted of different ethnic elements. Emphatically, the term "Mongol" is used in this paper to indicate those peoples of the Great Mongol Empire who, regardless of their ethnic background, were members of the empire's ruling and/or military elite and can be identified by their gravegoods and in pictorial representations by wearing "typical" Mongol costumes. To define the precise meaning of this expression and the different virtual messages of these clothes inside and outside the empire are the subjects of this paper.

\section{Historical Background: the Great Mongol Empire}

The Great Mongol Empire was the "largest transcontinental (contiguous) empire of the pre-modern world" (Morgan 2007, p. 5). It was founded by Chinggis Khan in the Mongolian heartland in 1206, and reached its greatest extension under his descendants during the 13th century. Before his death, Chinggis Khan allotted appanages (ulus) to the members of his family, and to some of his generals (Jackson 2009, pp. 39-40). By the end of the 13th century the Great Mongol Empire had disintegrated and there were four appanage empires under the Chinggisids' rule: the Jochid realm (Jochi's ulus) in the northwest, the Chagatai Khanate in the west, the Ilkhanate in the southwest, and the Yuan Empire in the east. Each khanate was ruled by the members of the Qiyat Borjigin clan, i.e. the Chinggisids (the altan uru $\gamma$ in Mongolian), who - along with the multiethnic military and administrative elite - constituted the ruling class (Morgan 2007, pp. 99-101). The Yuan Dynasty (大元國 Dà Yuán guó) was founded by Qubilai in 1272, after he chose a Chinese name, Yuan (meaning "Origin") for his dynasty (Rossabi 2011, p. 7; 1994, p. 458). His realm included most of the territory of present-day Mongolia and China. In spite of the political disintegration, the khanates of the Great Mongol Empire, the Yuan Empire in particular, belonged to the most important and powerful political entities in Eurasia until the mid-14th century. Not only their military might but also their crafts and commerce made their influence felt even outside the empire. Their clothing played an especially important role in their political culture and according to Thomas T. Allsen, it was their nomadic cultural heritage that made the Mongol elite to consider textile and clothing as their true display of wealth and power (Allsen 2001, pp. 99-108).

\section{Recent Archaeological Discoveries of Yuan Clothes}

\subsection{The Cave Burials of Mongolia}

Until recently, we had only written sources on the visual representations of the clothing of the Yuan Empire. However, in the 20th century, and especially during the last two decades several important archaeological discoveries were made in Inner Mongolia (in China) and Mongolia, from the territory of the former Yuan Empire (Lxagvasüren 2007; Baiarsaikhan 2009; Zhao Feng-Wardwell-Holborn 2004; Oka 2009). The burials at Buxiin Xušuu and Nartiin Xad belong to the numerous cave burials of 
the Great Mongol Empire. The former was discovered at Buxiin Xušuu, in Delgerxaan sum, in Xentii aimag (Baiarsaikhan 2009), the latter was explored in a cave at Mt. Ix Nartiin Čuluu, in Dalanjargalan sum, in Dornogov' aimag. Thanks to the arid climate, many textiles and other objects made of perishable material were in exceptionally good condition at the time of their discovery. According to Jamsarjaw Bayarsaixan, the archaeologist who published the burial from Buxiin Xušuu, the person buried there was an "average" member of the military elite. His opinion, which I share, was based on other grave goods of the deceased person. If his garments had not survived, it would not be considered a rich burial. The lady's burial from Nartiin Xad seems to belong to the same category.

\subsection{The Findings from Buxiin Xušuu and Nartiin Xad}

\subsubsection{The Cave Burial in Buxiin Xušuu}

The man who was buried in Buxiin Xušuu had three coats.

Buxiin Xušuu, coat No. 1: white tabby silk coat with green-gold lampas appliques and embroidered waist-decoration: Plate 1.

The reconstruction of Buxiin Xušuu, coat No. 1: Plate 2.

Buxiin Xušuu, coat No. 2: green lampas coat with string waist decoration Plate 3.

Buxiin Xušuu, coat No. 3: green lampas coat with embroidered waist-decoration Plate 4.

These garments had several similar features in their appearance. Two of them (coats Nos 2 and 3) were made solely of golden lampas of green colour. One coat (coat No. 1) was made of (white tabby silk, and only its applied decoration was made of similar lampas. The garments were open in the front, and overlapped to the right. They were tied on the right with pairs of ribbons, and in one case, knotted buttons. Their under-lapping were to the left, and were supposedly fastened in a similar way, inside the garment. Each coat has a shawl-collar, which follows the upper edge of the overlapping, the back and the under-lapping. Their long, ample sleeves are cut in prolongation of the body, tapering toward the wrist, and have cuffs. The waist of the garments is covered with couching, made of horizontal rows of silk strings or in one case (coat No. 2) cords. They are lined with similar, low-quality, loosely woven tabby silk, and may have been padded. We do not know the height of their owner, but it seems that the coats' lower hem did not reach the ground. As the grave was robbed, we do not know for sure in what sequence they were put on each other, but coat No. 1 with the applied decoration seems to be the innermost layer of the three. Several kinds of golden green textiles were used for the applied decoration of coat No. 1 in a conscious, careful, well-balanced design, where the main lines were accentuated and the disturbingly dissimilar patterns, obscured by embroidery, look as if fine braided silk threads were used for couching. A similar couching covered the waist of two coats No.1 and No. 3 . In spite of their appearance, these "braids" consist of pairs of silk threads, which were twisted in opposite directions, then sewn together, then on the robe. Instead of embroidery, the waist decoration of robe No. 2 is made of horizontal rows of textile cords, perhaps one single continuous cord, which was made of golden lampas. 


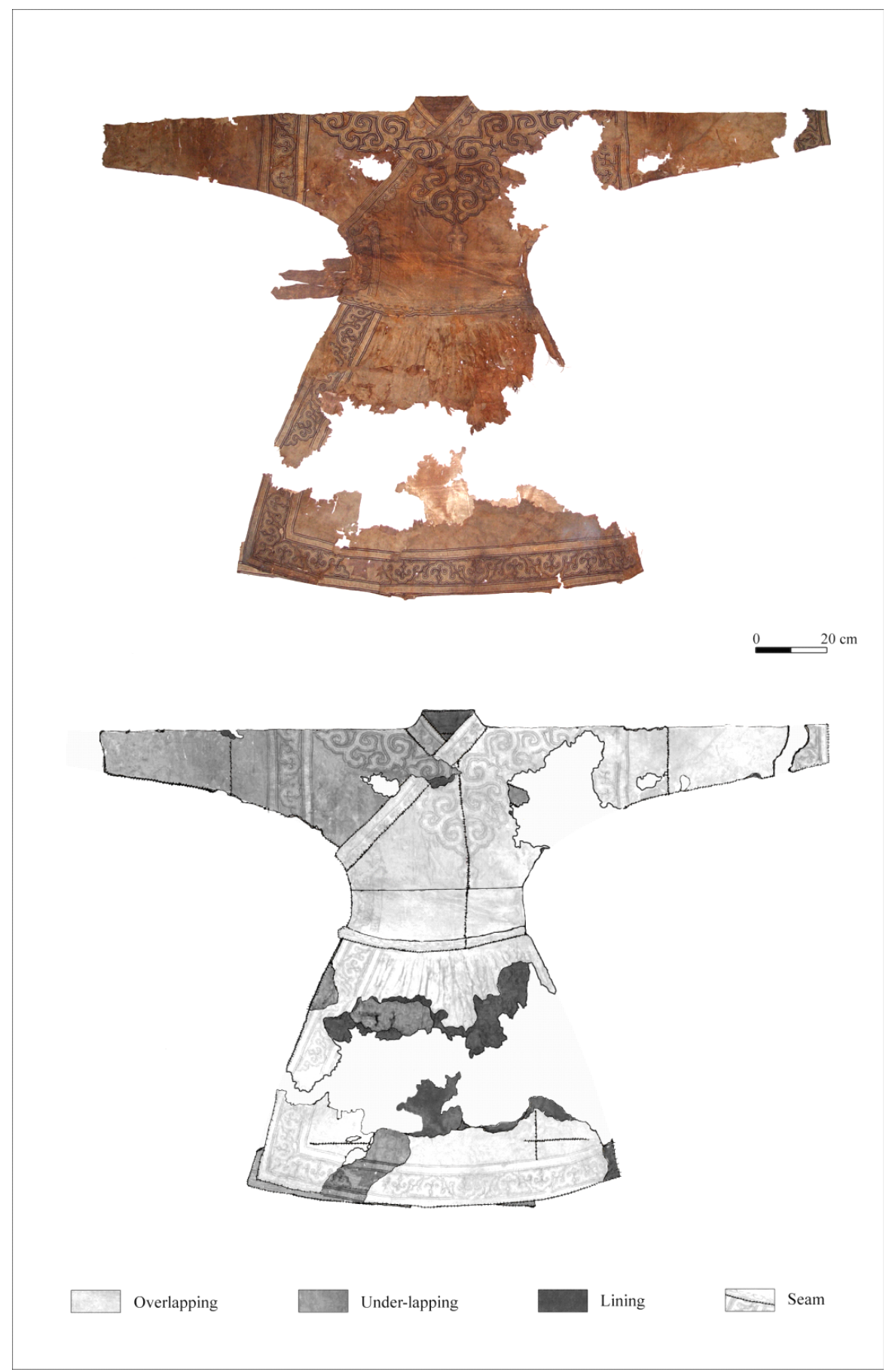

Plate 1. Coat No. 1 from Buxiin Xušuu 


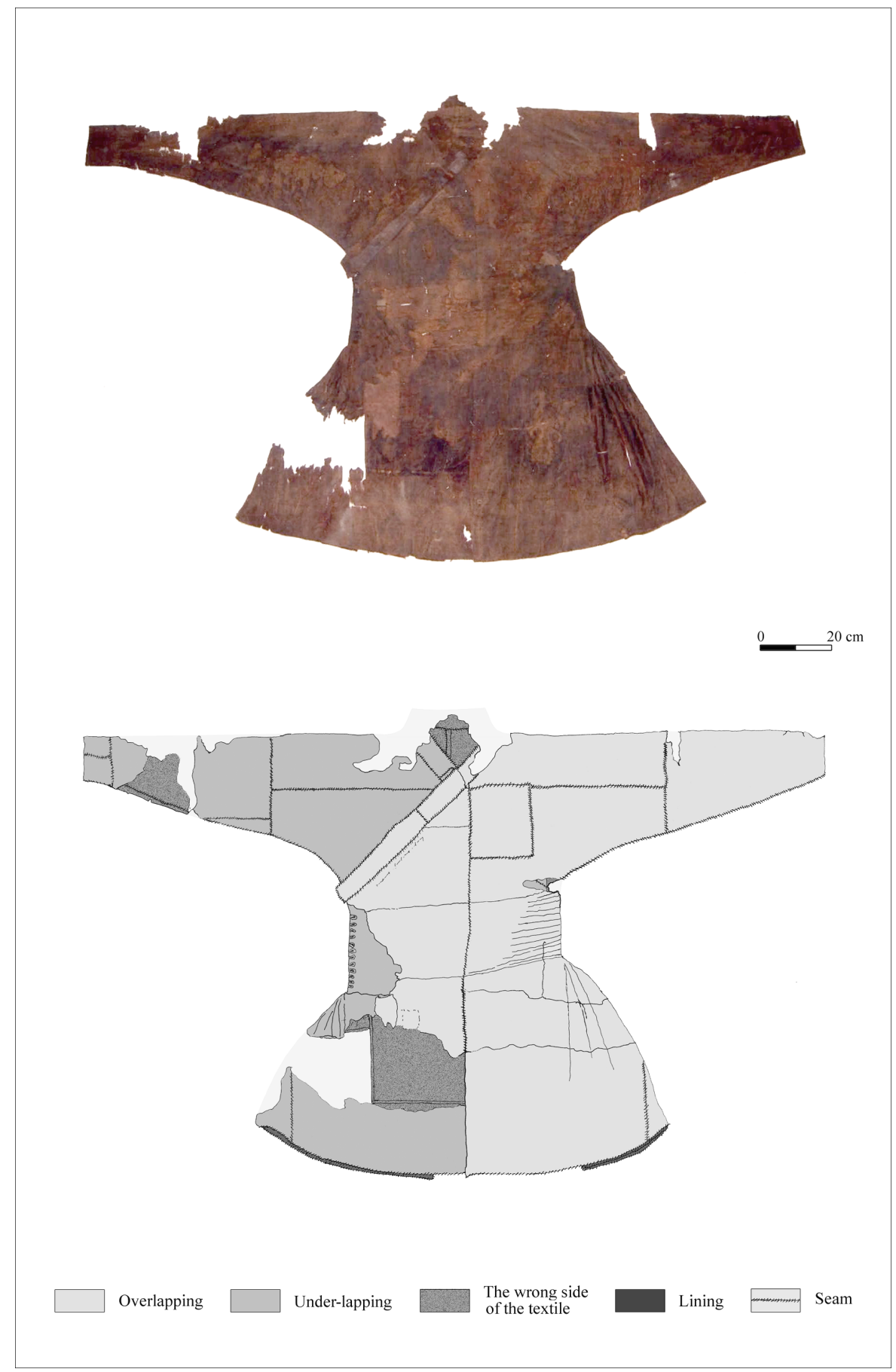

Plate 2. Coat No. 2 from Buxiin Xušuu 


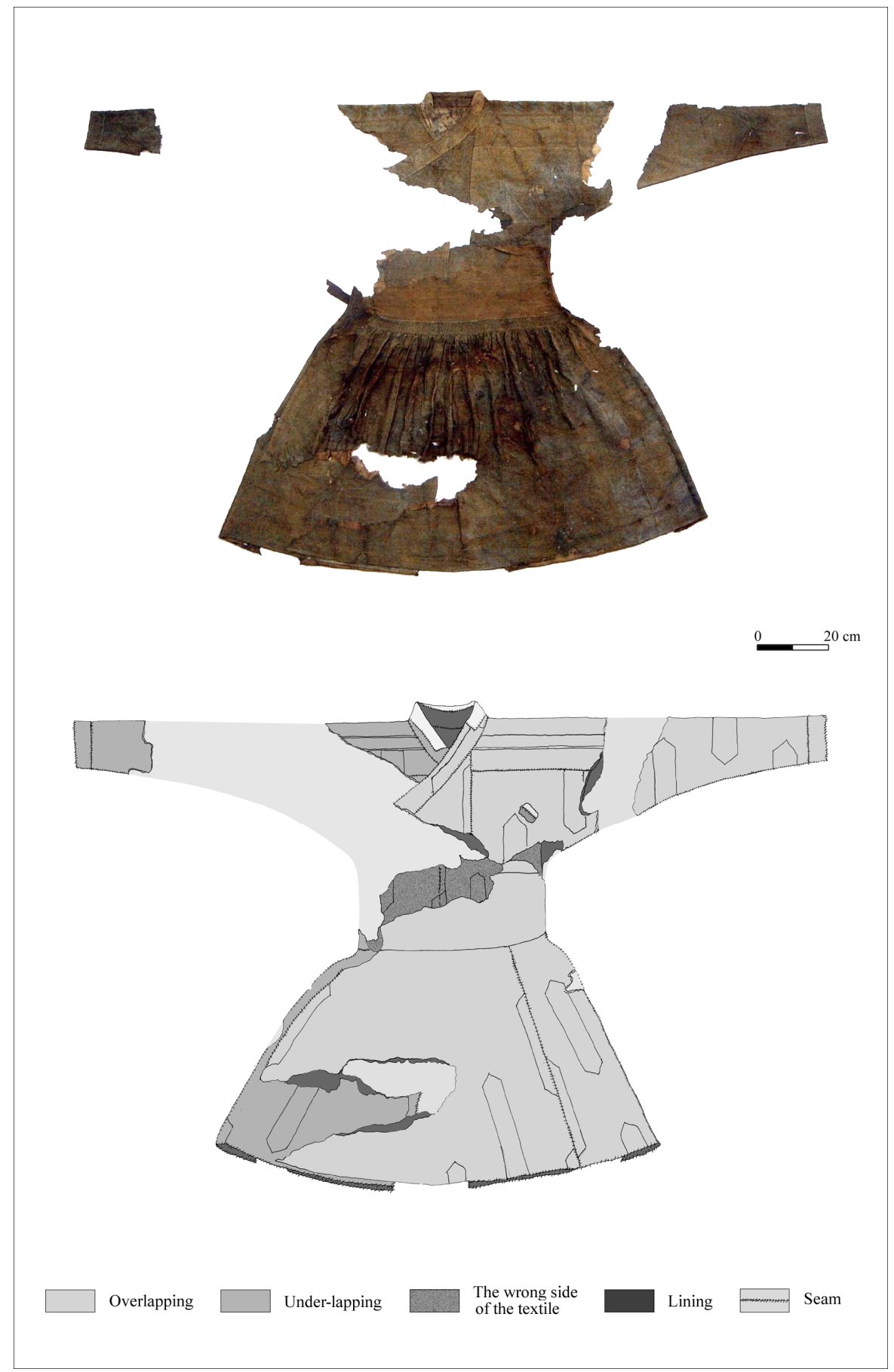

Plate 3. Coat No. 3 from Buxiin Xušuu 

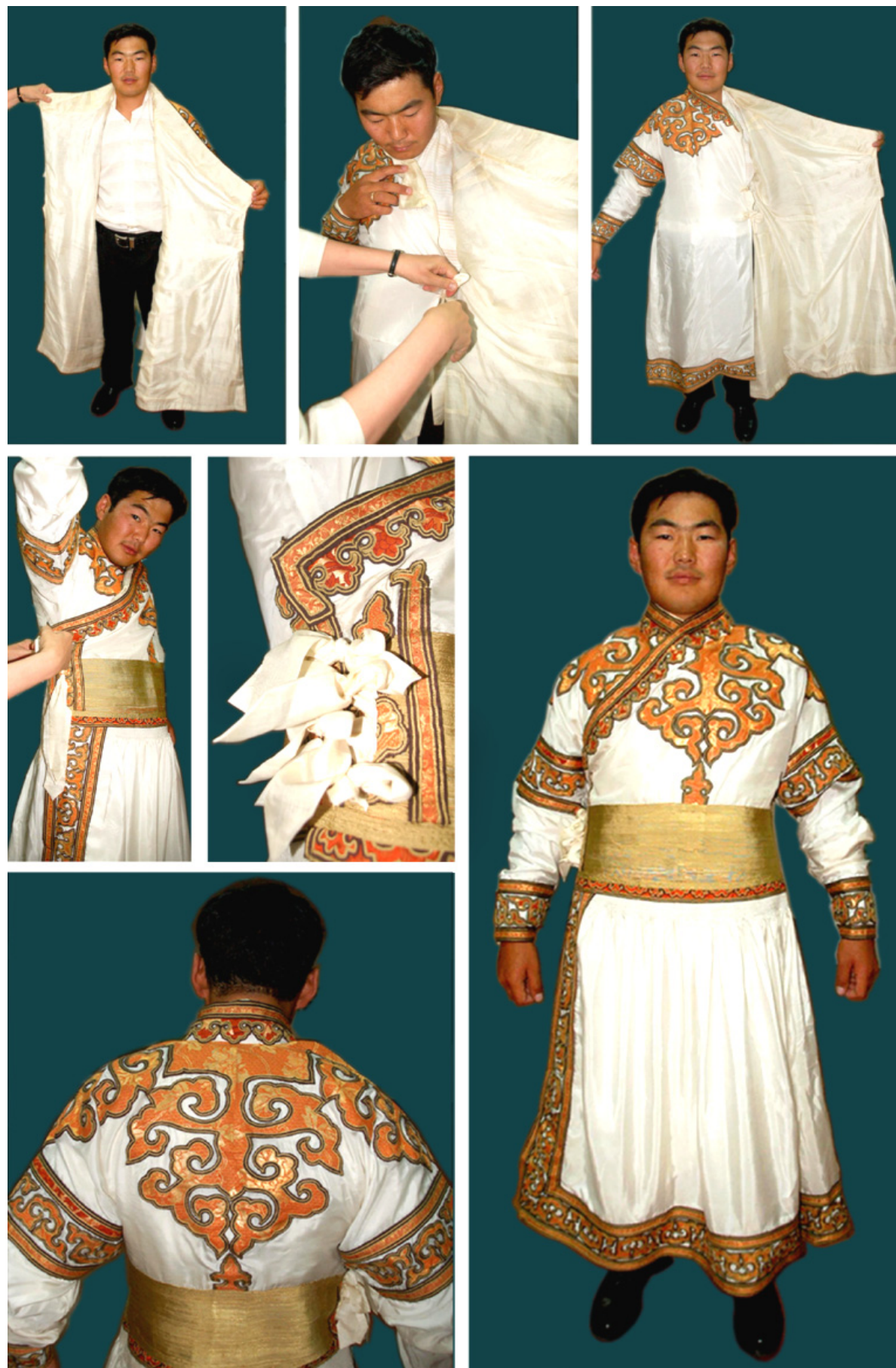

Plate 4. The reconstruction of coat No. 1 from Buxiin Xušuu 
Despite the similar appearances of the coats, their cuts are different. Two of the garments have a cross partition under their waist-decoration (coats Nos 1 and 3). The lower part of the coats forms a skirt ("petticoat"), which is gathered in such narrow plaits what only highly trained specialists can produce. One of the coats (coat No. 2) was made without the cross partition, consequently, its skirt cannot be plaited. Instead, it has wide folds at the sides, folded inside the coat. In spite of their different cut, the outlines and the proportions of the coats look similar. ${ }^{1}$ The design units of the textiles of coats No. 2 and No. 3 are so large that they have to be seen only in an upright position, so the front and the back of the coats could not be made of one piece of cloth. On the top of the original end of the textile panels there are bands composed from interlaced Kufic shafts. These bands are placed on the shoulders of these coats, so there must be seams joining them to the other textiles. In these cases, the seams are not functional, but still serve an important decorative purpose. Interestingly, the tailors used scraps of similar bands to make the shoulder-part of the textile panel for the cloudcollar of coat No. 1, even though its pattern was obscured by trimming and couching.

\subsubsection{The Cave-burial in Nartiin Xad, Dalanjargalan Sum, Dornogow' Aimag}

In Nartiin Xad an old woman was buried (Erdenbat-Xürelsüx 2007, pp. 332-359). Her grave goods were not exceptionally rich, but she was buried with three garments: a cegdeg 'female under dress' (Nartiin Xad Robe No. 4: Plate 5) a "ceremonial silkcoat" (Nartiin Xad Robe No. 5: Plate 7) and a "winter coat" (Nartiin Xad Robe No. 6: Plate 8$)^{2}$

Nartiin Xad Robe No. 4 "cegdeg” (female under dress): Plate 5.

The cut of Nartiin Xad Robe No. 4: Plate 6.

Nartiin Xad Robe No. 5: "ceremonial silk-coat", Plate 7.

Nartiin Xad Robe No. 6: "winter coat", Plate 8.

The cegdeg, the female under dress (Nartiin Xad No. 4: Plates 5-6) looks like a home-made variation of the male coats with the horizontal cross-partition. It was made of loosely woven red tabby silk - similar to the linings of the other coats in quality, but of much deeper colour - except its shawl collar, cuffs and the hemming of the skirt, which have been made of patterned white brocade. Obviously, only this part of the robe was visible; it must have been an undergarment. It has not been lined but its appearance is misleading: this robe is not a coat, which has to be "put on" - it is something to "pull over". It has no frontal opening, like the other types of Mongol clothing; it is a dress, which has been made to look like a coat but it was not, i.e. it was not open in the front.

${ }^{1}$ Some of the seams of the coats are not functional, that is they do not alter the form of the coat: it does not matter if a basic part or panel of a dress, which must be flat in its original state, has been cut of one single piece of cloth, or it has been made by sewing together several pieces of smaller textiles. When I talk about the seams of the coats, I mean only the functional ones.

${ }^{2}$ The English names of the garments are given in the summary of U. Erdenbat and S. Xürelsüx's article. The numbering is mine (Erdenbat - Xürelsüx 2007). 


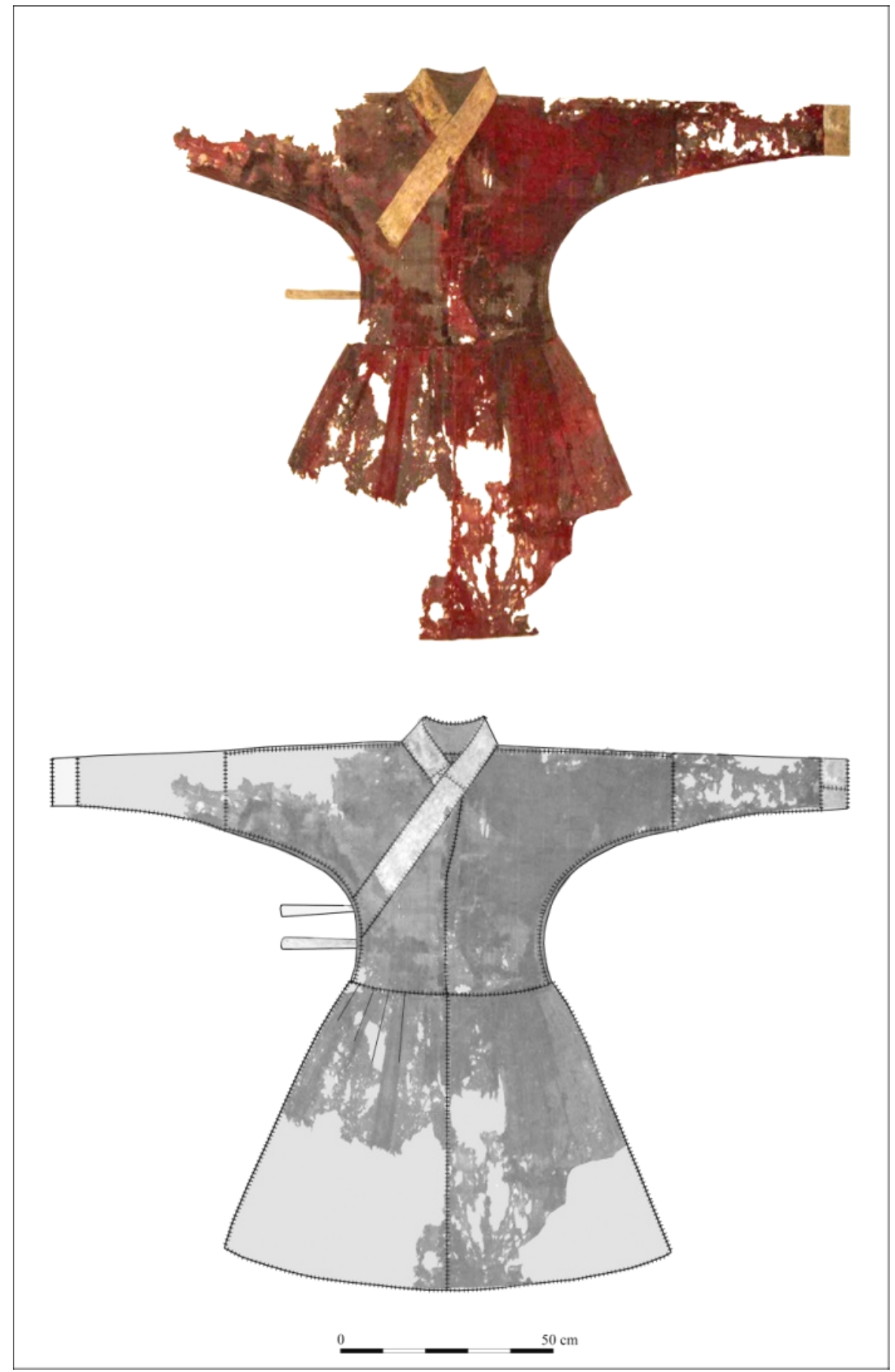

Plate 5. Robe No. 4 (under-caftan) from Nartiin Xad 


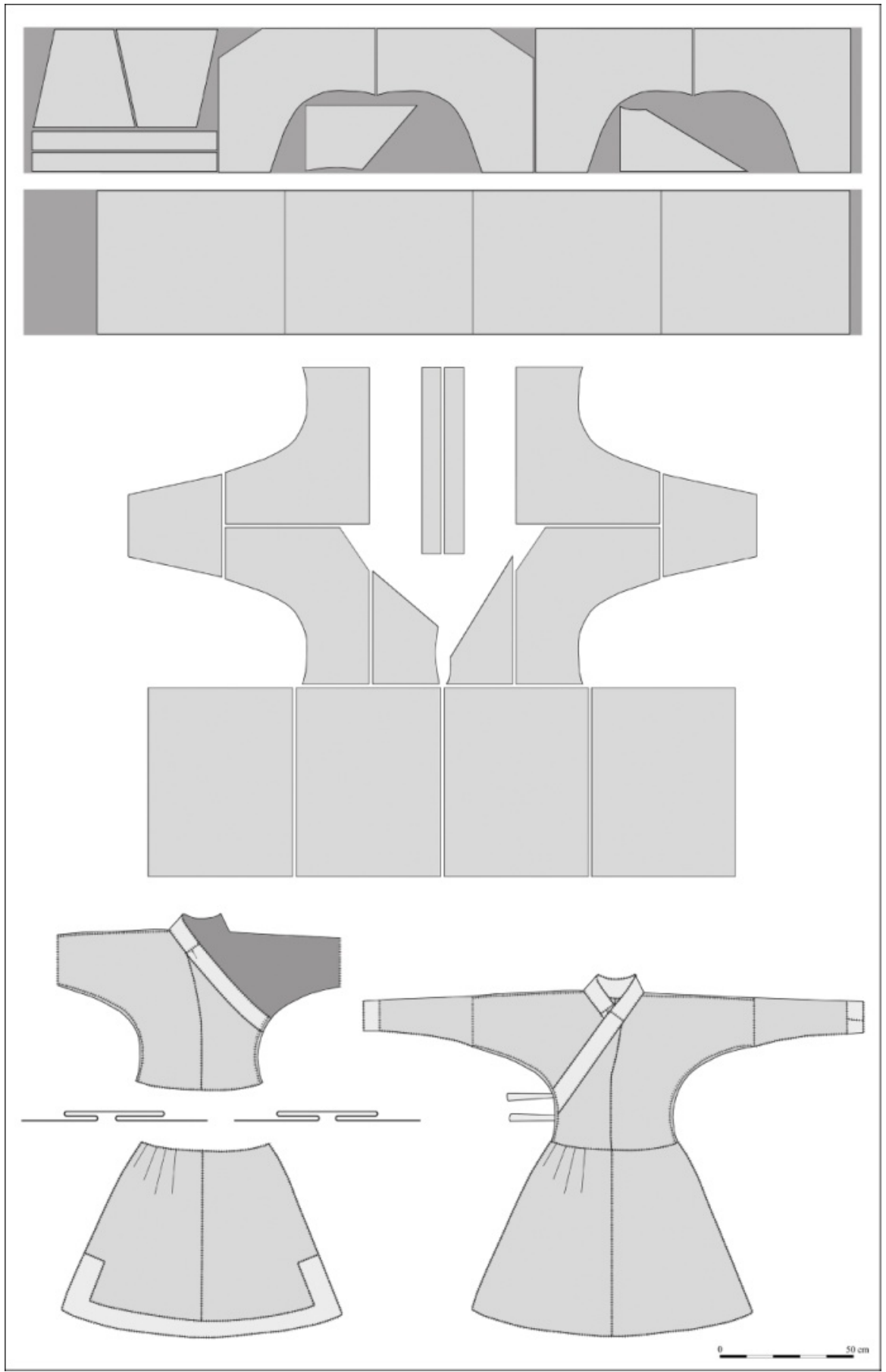

Plate 6. The cut of robe No. 4 from Nartiin Xad 


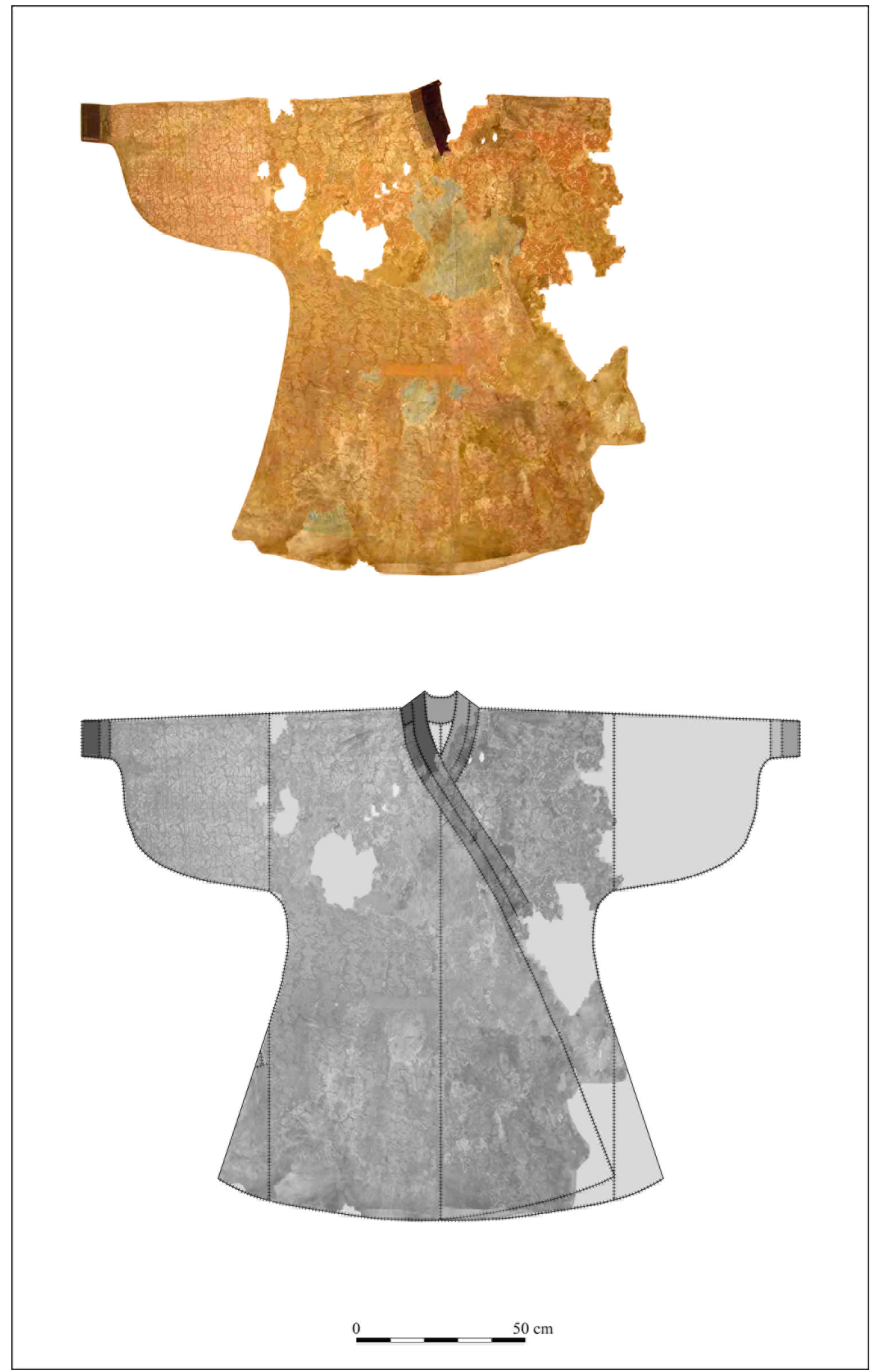

Plate 7. Robe No. 5 from Nariin Xad 


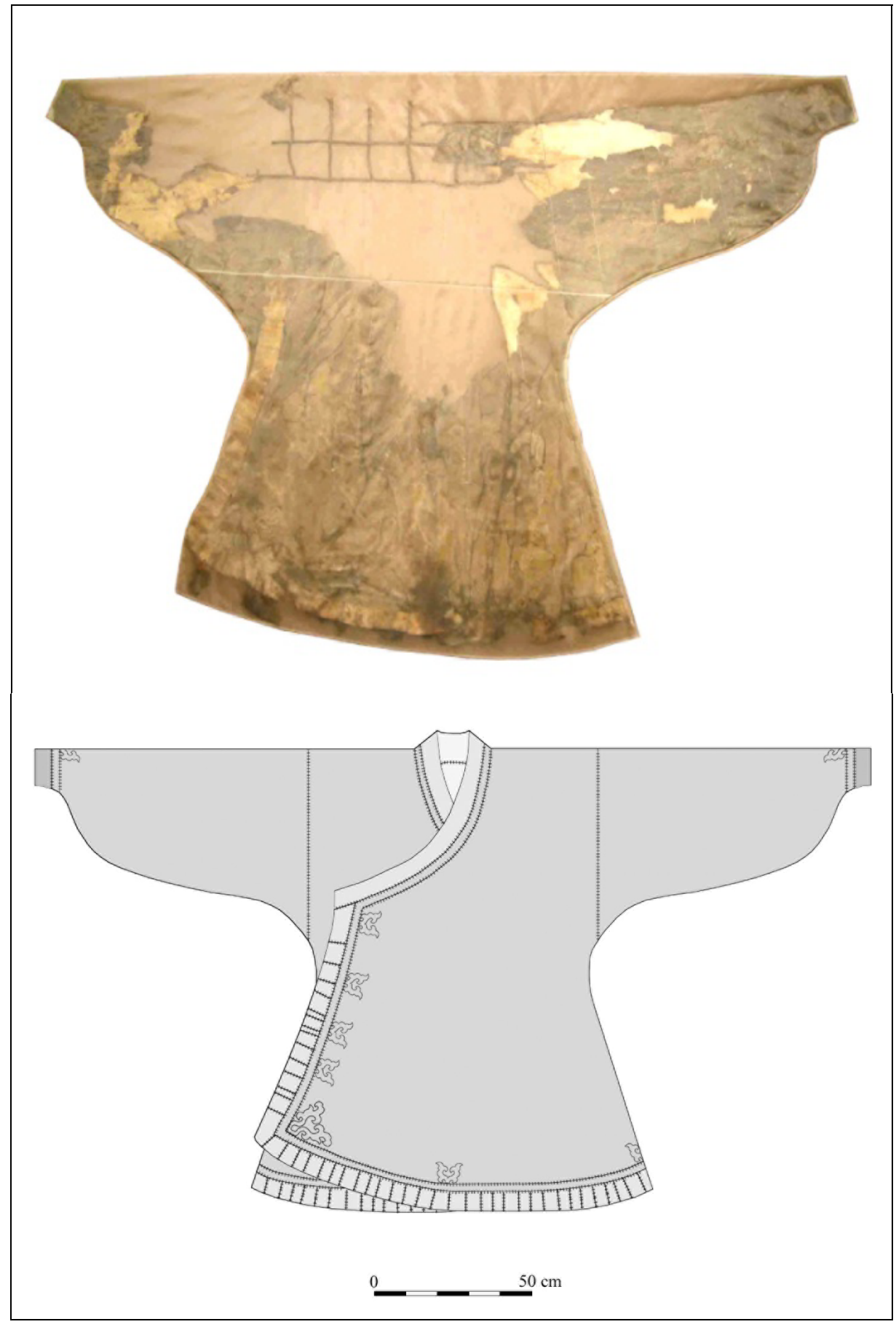

Plate 8. Robe No. 6 from Nartiin Xad 
The silk coat (Nartiin Xad No. 5: Plate 7) was made of red golden lampas. The garment's front overlapping is completely missing, but there is no doubt that it was fastened on the right. It has wide, long sleeves, rounded off at the end and leaving narrow openings only for the hands with short, tight cuffs. The cuffs and the double shawl collar of the coat have been made of several small pieces of purple textiles (Oka 2009).

The outline and some details of the fur winter coat (Nartiin Xad No. 6: Plate 8) certainly looks very similar to that of the lampas coat, but because it is presently enclosed in a bag and we have no photographs of its original state, some of its important characteristics cannot be defined. ${ }^{3}$

\subsection{Identification of the Textiles}

The No. 2 and No. 3 coats from Buxiin Xušuu and the No. 5 coat from Nartiin Xad and the applied decoration of the No. 1 coat from Buxiin Xušuu were made of golden lampas. The overwhelming majority of these textiles have been woven with the technique and designs characteristic of the Eastern Iranian world (Watt-Wardwell 1998, pp. 126-145) ${ }^{4}$ (Plate 3). Their closest parallels are now in the collection of The Cleveland Museum of Art. ${ }^{5}$ On the other hand, a small part of the cloud-collar of coat No. 1 has a Chinese dragon-pattern.

The red-golden brocades of the lady's No. 5 robe from Nartiin Xad (Plate 7) was woven in the Chinese way, and has a Chinese-looking pattern, but the purple textiles used for its collar look Western-Asian. Like the decoration of the No 1 coat from Buxiin Xušuu (Plates 1 and 2), the two-layered collar has been made of small pieces of different textiles: the value of the gold brocade seems to be more important that the "patched up" appearance of the gown. There are similarly produced coats from Inner Mongolia (Zhao Feng - Wardwell-Holborn 2004), from the Jochid realm (Orfinskaja-Lantratova 2011a, 2011b), and those of unknown provenance like the Mongol coat Inv. no. 23/2004 from The David Collection, Copenhagen, etc. Anne Wardwell identified the above-mentioned parallels of the silks ${ }^{6}$ from Buxiin Xušuu as the "nasij" or "na-shih-shih" which is defined as gold brocade (chin-chin) in the Yuan shih, the official history of the Yuan Dynasty compiled by the Ming (Allsen 2001, pp. 2-3). ${ }^{7}$ The gold threads of the coats from Buxiin Xušuu are made of gilded

${ }^{3}$ For instance, it is not sure whether the frontal central vertical seam is really missing or not. The main body of the coat has been sewn together from several small pieces of leather, so this seam would not be essentially functional or necessary.

${ }^{4}$ For detailed technical analysis see Oka (2009).

5 "Cloth of Gold with Winged Lions and Griffins" The Cleveland Museum of Art Purchase from the J. H. Fund (1989.50) and "Cloth of Gold with Displayed Falcons" The Cleveland Museum of Art Edward L. Whittemore Fund (1996.297) (Watt-Wardwell 1998, pp. 126-128, 134, 142 $145,154-155)$.

${ }^{6}$ See footnote No. 4.

${ }^{7}$ Nasij textiles have been woven in lampas weave with gold threads, in which there are two sets of foundation silk weft and supplementary patterning wefts. The foundation warp and foundation weft established the foundation weave and the (secondary, supplementary) binding warps bind the 
strips of animal substrate wrapped around an undyed silk core, and the gold thread of silk coat No. 2 from Nartiin Xad is composed of strips of gilded paper, woven flat. Generally speaking, the first type of gold thread was usually used in the Central-Asian, Iranian and European textiles, and the second in Chinese and Eastern Asian textiles. But coat No. 1 of Buxiin Xušuu and coat No. 2 from Nartiin Xad each contains textiles woven in the other way.

The Mongols resettled artisans from every territory of their vast domain and put them to work in the imperial textile workshops (Allsen 2001). At least five of them produced nasij, and in three workshops ${ }^{8}$ Central Asian and Chinese artisans worked together (Allsen 2001, pp. 39-45; Watt-Wardwell 1998, pp. 130-131). The result of the forced resettlement of these craftsmen was an East-West cultural exchange of the weaving techniques and designs. The finds from Buxiin Xušuu and Nartiin Xad seem to have been made in workshops where artisans who have been trained in different weaving techniques and learnt different textile patterns worked together: this corroborates the written evidence that in some workshops West Asian weavers trained Chinese to weave nasij (Allsen 2001, p. 96; Watt-Wardwell 1998, pp. 127-141). ${ }^{9}$

\subsection{Identification of the Costumes}

\subsubsection{The Male Costume}

We have three coats from Buxiin Xušuu. The written sources (Plano Carpini II. 4, 5 and Rubruk VI. 3) describe the male and female coats as having the same cut; in other words, open in the front and double breasted, and fastened on the right at three, on the left at one place. If we interpret Plano Carpini's words (Plano Carpini II. 4) that the coats were "fastened on the right on three places" with three pairs of ribbons or strings and "fastened on one place on the left" with a pair of ribbons inside the robe, it describes (almost) perfectly the coats No. 1 and No. 3 from Buxiin Xušuu, though the number of the pairs of ribbons is not always the same. ${ }^{10}$ Each of these robes had been made of golden lampas, which has been identified as nasij. The technical charac-

gold threads of the supplementary wefts to make a pattern. The gold threads of the weft are made of gilded (sometimes silvered) strips of animal substrate wrapped around an undyed silk core, or gold thread composed of strips of gilded (sometimes silvered) animal substrate or paper, woven flat (Allsen 2001; Watt-Wardwell 1998, p. 127).

${ }^{8}$ They were in Daidu (present-day Peking), in Hongzhu (present day Yangyuan, Hebei) and in Xunmalin (near present day Zhangjiakou, Hebei).

${ }^{9}$ Experts agree that there was an "unprecedented flourishing" of this type of gold brocade in the Yuan Empire (Kuhn-Zhao Feng 2012, p. 334) and admire the "extraordinary imagination and vitality" (Watt-Wardwell 1998, p. 130) how the different cultural elements were merged and combined to form a distinct new style. When Wardwell described the designs on the Cleveland textiles, she said that "it is neither Chinese, nor Islamic, but Central Asian" (Watt-Wardwell 1998, pp. $127-128,144)$.

${ }^{10}$ For instance: Zhao Feng - Wardwell - Hollborn (2004, pp. 38-39): Robe with 'all-weather' sleeves: the number of the ribbons $3 \times 2$ on the right, $1 \times 2$ on the left (inside the robe), pp. $48-50$ : Robe with silk braiding decoration: number of ribbons $5 \times 2$ on the right. 
teristics and the style of their pattern connect these textiles to Central Asian, possibly Yuan workshops, and all of them are of one colour.

According to the written sources, the nasij was woven not only for the consumption of the imperial court, but for the "robes of honour" of the Mongol Empire. Robing was not a unique Mongol custom; it was an international institution, which had an important role in the investiture in ancient, mediaeval and premodern Eurasia. The Mongol "robes of honour" were usually of one colour (jisun in Mongolian, jamah in Persian, chih-sun in Chinese) and are often mentioned in the sources. Originally, it meant "colour" but in the Yuan shih its meaning became "a robe of one colour" (Allsen 2001, pp. 19-22). At the great official parties of the Mongol Empire, the participants were obliged to appear dressed in the same colour; these festivities were called, appropriately, jisun banquets. Nevertheless, the nasij made the Mongol Empire's robes much more valuable than the other robes of honour; the Mongols, for a while, owned all the resources necessary to produce and give away an enormous quantity of nasij robes, not only to their subjects, but foreign guests and envoys too. ${ }^{11}$

Their colour and the material they were made of, identify coats No. 2, No. 3, and perhaps No. 1 of Buxiin Xušuu as nasij jisun coats.

The appearance and outline of the coats from Buxiin Xušuu are comparable not only to each other but to several similar coats from the Mongol imperial era.

\subsubsection{The Female Costume}

The deceased woman from Nartiin Xad was buried with the quintessential Mongol headwear, the bogtag; the sources say that this hat identified their owners as married Mongol women (Plano Carpini II, 4, 5; Rubruk VI, 30). ${ }^{12}$ These sources do not give us very detailed information about the Mongol women's robe, except that it was very wide, open in the front, double-breasted and fastened three places on the right and one (supposedly inside the coat) on the left. Plano Carpini says that the male and female cloths were cut in the same way and the fur coats were similar to them, too. The costumes from Nartiin Xad fit into this description. Coat No. 2 was made of jisun nasij of one (red) colour and its material and craftsmanship point to the imperial workshops. When we compare it to the unskilful sewing of the undergarment No. 1 from Nartiin Xad, the difference between them is striking. Robe No. 1 seems to be home-made, its appearance reminds us of the male coats, and was made of law-quality textiles. The contour of the No. 3 fur coat resembles that of the nasij cloth, but we do not know much about its details. The most surprising feature of the finds is how the sophisticated design of the nasij male coats were copied and used on female costumes of completely different cut, material and standard.

11 "Muslims robed Jews and Christians, Byzantines robed Armenians, Armenians robed Abkhaz, and the Mongols, it seems, robed everybody else" Allsen (2001, p. 86). Marco Polo has written that the Great Khan (Qubilai) presented robes of gold and silver textiles in each (lunar) month to the kesigten, and the number of these robes was altogether 156,000 in a year (Yule-Cordier 1920, p. 394).

${ }^{12}$ The italics are mine. The Latin original and a translation by Richard Hakluyt can be read online: https://archive.org/details/textsversionsofj00hakluoft. 


\section{Finds from Other Areas}

\subsection{Similar Finds from the Yuan Empire}

\section{Male Coats}

No. 7 "Damask robe with ribboned waist decoration" (Zhao Feng-Wardwell-Holborn 2004 pp. 44-47) (Plate 9/2).

No. 8 "Robe with silk braiding decoration" (Zhao Feng-Wardwell-Holborn 2004, pp. 48-53) (Plate 9/1).

No. 9 "Robe with braided waist" found at Mingshui (Zhao Feng-Wardwell-Holborn 2004, p. 49).

No. 10 "Robe with all-weather sleeves" (Zhao Feng-Wardwell-Holborn 2004, pp. $38-43)$.

No. 11 "Robe with braided waist" found at Mingshui (Zhao Feng-Wardwell-Holborn 2004, p. 49).

The minute plaits of their skirts, the shawl collars, the silhouettes, measures and the proportions of these coats are very similar to the coats' from Buxiin Xušuu and to coats No. 8 and No. 9 made of golden lampas, and robe No. 7 was made of damask. The waist of this coat was covered with horizontal rows of ribbons instead of couching, and it was fastened with knotted buttons, just like coat No. 2 .

But the coats of the Yuan Empire were by no means uniform. We have already seen that one of the three garments from Buxiin Xušuu (coat No. 2) had no crosspartition, and its skirt was not plaited. Zhao Feng considers a "robe with all-weather sleeves" a "standard product of the Yuan in both its cut and general styling", though it has no horizontal cross-partition (Zhao Feng-Wardwell-Holborn 2004, pp. 38-43). It looks very much like coat No. 2 from Buxiin Xušuu, but the waist-decoration is lacking; it seems that it was not an indispensable part of the "Mongol" or even the Yuan coat (Zhao Feng-Wardwell-Holborn 2004, pp. 38-43).

\subsection{Similar Finds from the Jochid Realms}

In the No. 63 Mogil'nik of Majačnyj Bugor I (Astrahanskaja oblast'), the deceased lady was buried wearing four layers of underwear and three layers of gowns, some of which were padded. In appearance and cut her "1st gown" the No. 1 under caftan from Nartiin Xad, but according to Lantratova it is a coat (Orfinskaja-Lantratova 2011b, p. 24, Table 2) ${ }^{14}$ Its colour is similar to the Nartiin Xad's dress, but in this case it was made of red gold brocade, and had trimmings of brown gold brocade. Her "2nd coat" (robe No. 13) which was worn on the top of the

${ }^{13}$ This is the numbering of Orfinskaja - Lantratova (2011b).

14 "Wrap-around", the same word what she uses for the 2nd coat. She also writes, that "it is detachable at the waist"; I think this means the same phenomenon that I defined as "horizontal crosspartition". 


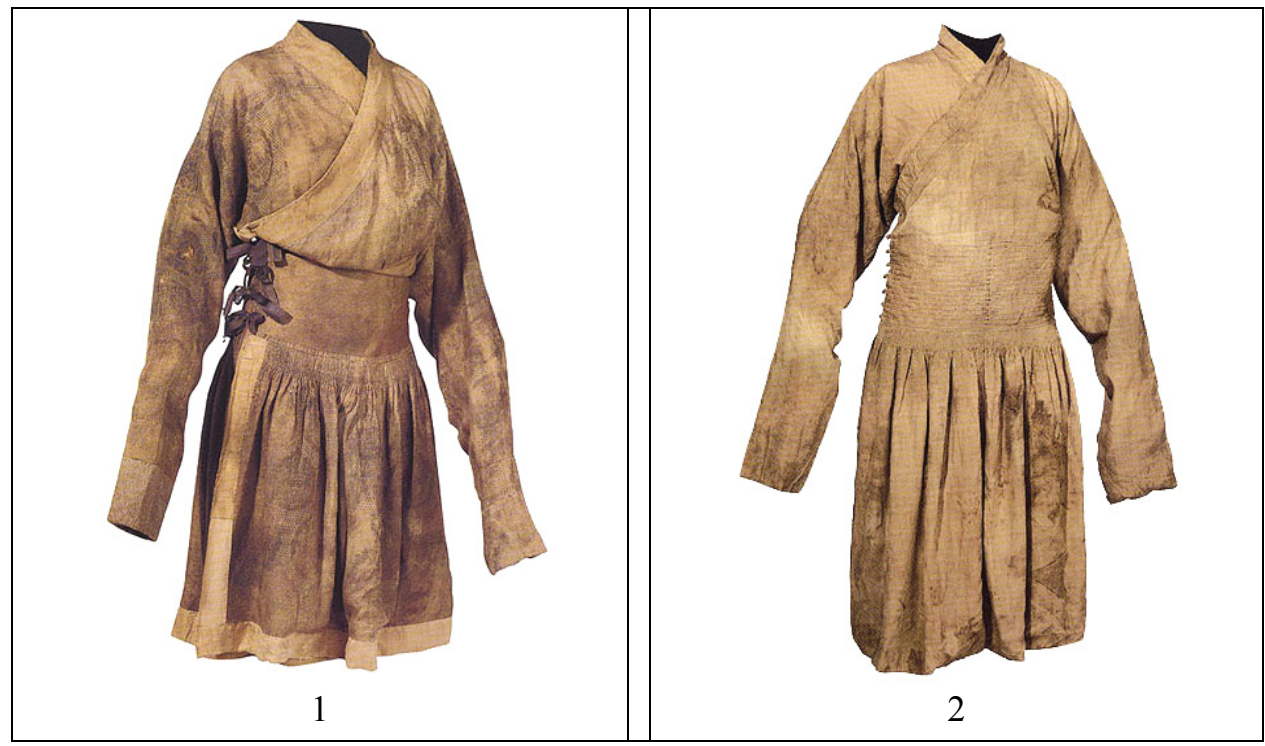

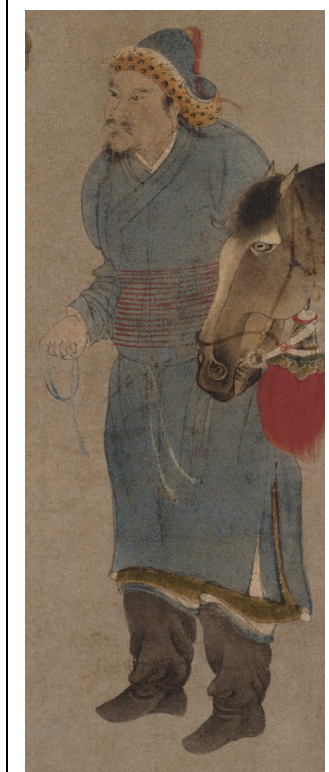

3

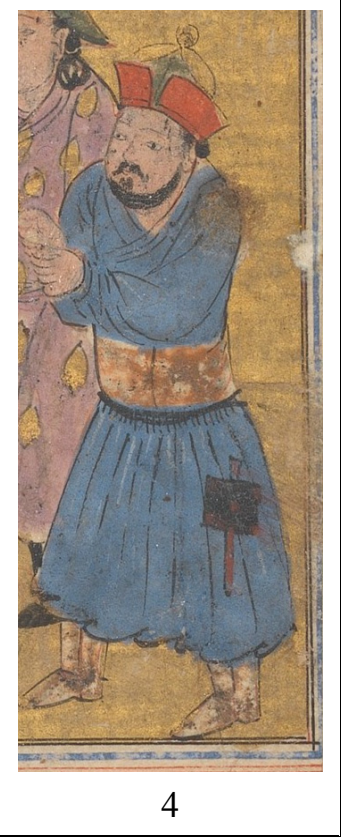

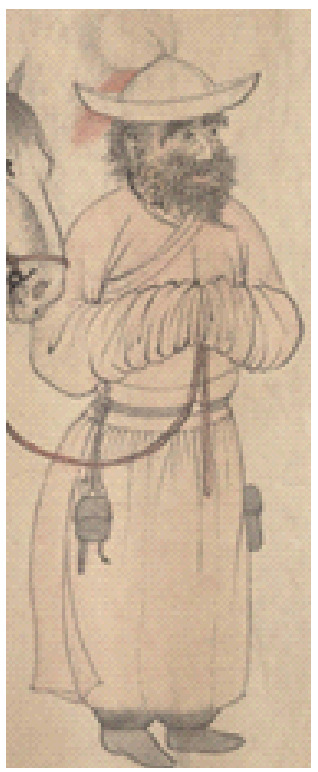

5

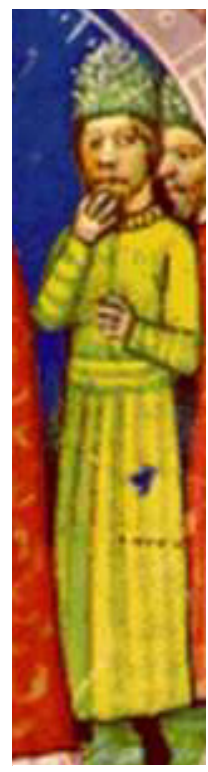

6

Plate 9. Variations of waist-decorations

(1) Mongol coat from Inner Mongolia, (2) Mongol coat from Inner Mongolia, (3) "Six Horses" Chinese handscroll, from The Metropolitan Museum of Art, Bequest of John M. Crawford Jr., 1988 (1989.363.5), (4) Kai Khusrau Enthroned Holding a Sword, Folio from a Shahnama, (5) Man and Horse Zhao Mengfu (Chinese, 1254-1322), dated 1296. The Metropolitan Museum of Art Gift of John M. Crawford Jr., 1988 Accession Number: 1988.135, (6) Miniature from the Chronicon Pictum p. 60 (f. 30a) 
"1st" (robe No. 12), had appearance and cut similar to that of the No. 5 gown from Nartiin Xad. It was made of gold brown silk with brown and red-brown gold brocade trimming. Her 3 rd gown was a short jacket. ${ }^{15}$

There is an obvious difference between the craftsmanship of the nasij robes and that of the under caftan: the tailoring of the 2nd coat shows features similar to the garments from Buxiin Xušuu; they have the same elegant outlines, even stiches, lining material and excellent craftsmanship. In some cases, the larger parts of the robes are sewn together from smaller textiles. The tailors sometimes used textiles with different designs, but always of the same colour. I think the nasij robes from Buxiin Xušuu were made in the workshops of the Yuan Empire. However, O. V. Orfinskaja and O. B. Lantratova consider the garments from the Burial 93 of Majačnyj Bugor I cemetery to have been made locally, possibly in the same household, and explain the number of layers by an alleged winter funeral (Orfinskaja-Lantratova 2011b, pp. 48-63).

A similar underwear was found in another female burial in the Majačnyj Bugor II cemetery. According to its schematic drawing and photographs (Lantratova et al. 2002, pp. 20-27), it is clearly a coat; it was fastened on the right with ribbons. The plaits of the skirt were not so narrow as those of the male coats from Buxiin Xušuu, its appearance is similar to the female under-caftan from Nartiin Xad (robe No. 4). According to the archaeological finds, it seems that a similarly looking garment was used in the Yuan and the Jochid realm; despite their political hostility, their clothing culture remained closely connected. Though I am not quite sure that they had the same cut, the appearance of their garments was certainly similar.

Other two garments were found in the 13th-14th-century grave of a woman at Verbovyj Log (Rostovskij oblast') (Vlaskin et al. 2006). They have a close similarity to the Nartiin Xad No. 4 and No. 5 gowns. The lady's short under-shirt belongs to a different type of clothing, but the cut of her gold brocade gown looks very much like the red nasij robe No. 2 from Nartiin Xad. Moreover, she had a black silk coat, lined with fur, which is comparable to the No. 6 fur coat from Nartiin Xad. The contours of the two coats are similar, except their collars; the fur coat from Verbovyj log has a layered standing collar which has connections to the earlier finds from Dugui Caxir (Bemmann 2012, pp. 296-297; Erdenbat-Amartüwšin 2010, p. 145; Vlaskin et al. 2006).

\subsection{Finds from Unknown Provenances}

Recently, several similar clothes appeared in the western market. Some of the closest parallels of the gowns from Buxiin Xušuu are now in private collections or museums. These costumes are usually attributed to Iran or Central Asia, but their exact prove-

${ }^{15}$ It has no parallel among our finds, and belongs to a different type of Mongol clothing. It has been made of golden brown brocade, and was trimmed with the same brown brocade as the 2nd gown was made of. The left-out parts of the 3rd gown were used for the trimming of the first. So in this case the three gold brocade gowns were made in the same workshop, perhaps at the same time, and valuable material was used for the underwear. According to O. V. Orfinskaja and O. B. Lantratova (2011b, pp. 48-63) these costumes were made in the same household. 
nances are unknown. They may come even from Mongolia or China. I mention just a few of them, unfortunately, their number is growing. ${ }^{16}$

A coat with knotted buttons is in the textile collection of the Agha Khan $\mathrm{Mu}$ seum, Toronto, Canada (Accession number AKM00677) which is considered to be from Iran or Central Asia and dated to the Ilkhanid period, 13th-14th centuries CE. ${ }^{17}$

A "Mongol Silk Lampas Weave Robe" was sold in Christie's Auction House in London in 2001. ${ }^{18}$

Caftan Inv. no. 23/2004 in the David Museum, Copenhagen. ${ }^{19}$

A Mongolian woman's coat from unknown provenance is in the $\mathrm{Mu}-$ seum of Islamic Art, Qatar ${ }^{20}$ (Plate 11/3).

A Mongolian woman's coat of unknown provenance is in an unnamed American private collection (Zhao Feng 2006, p. 89, figure 7).

A Mongolian woman's robe of unknown provenance, presumably from Inner Mongolia is in the collection of Meng Yuan Wenhua Bowuguan (Museum of the Mongol Culture), a private museum in Xöxxot (Zhao Feng 2006, p. 89, figure 6).

The above-mentioned male robes are very close to the green nasij coats from Buxiin Xušuu; two of them (the coat sold on Christie's and the one from The David collection) are fastened with ribbons like the No. 1 and No. 3 coats from Buxiin Xusuu, and one (the coat from the Agha Khan Museum) has knotted buttons, like the No. 2 coat from there, but the colour, the silhouette, the proportions, the waist-decoration, the plaited skirt and many other details of these gowns are all very similar to each other. The placement of the Kufic inscriptions on the shoulders points to a similar cut, too. The female coats have the same characteristics as the Nartiin Xad coat No. 5; it seems that this type of female overcoat had fewer variations than the male coats. The robe in the Meng Yuan Wenhua Bowuguan has the same silhouette, the long, narrow sleeves, horizontal cross-partition and the plaited skirt as the No. 4. Robe (under-caftan) from Nartiin Xad, but there is no false overlapping on the upper part of the robe, no effort to make it look like a coat. Only its neck-opening has the same appearance as the upper part of a shawl collar: perhaps only this part of the robe was meant to be seen.

${ }^{16}$ I mention only those male costumes which have the "braided" waist decoration.

${ }^{17} \mathrm{https} / / /$ www.agakhanmuseum.org/collection/artifact/robe-AKM677 (Retrieved on 09.09.2015).

${ }^{18}$ Sale details: Sale Title ISLAMIC ART AND MANUSCRIPTS Location London, King Street Sale Date Oct. 16, 2001 Lot Number 256 Sale Number 6497, from "Eastern Iran or Central Asia, late 13th or first half 14th century".

${ }^{19}$ It is "from the Eastern Islamic world or China, 1st half of 14th century", "sewn from a lampas-woven textile, silk with gilded lamella of animal substrate" and fastened with ribbons. http://www.davidmus.dk/en/collections/islamic/dynasties/il-khanids/art/23-2004, http://www.david mus.dk/files/c/2/331/11.1-23-2004-Mongolsk-dragt-1.jpg; http://davidmus.dk/files/e/f/332/11.1-232004-Mongolsk-dragt-2.jpg; http://davidmus.dk/files/f/f/334/11.1-23-2004-Mongolsk-dragt-3.jpg (These websites were retrieved on 09.09.2015).

${ }^{20} \mathrm{It}$ is considered to have been made in Central Asia, in the 13th century, http://www. google artproject.com/en/gb/collection-the-museum-of-islamic-art-qatar-artwork-mongolian-womans-robeunknown-central-asia-13th-century 1929321\# (retrieved: 09.09.2015). 

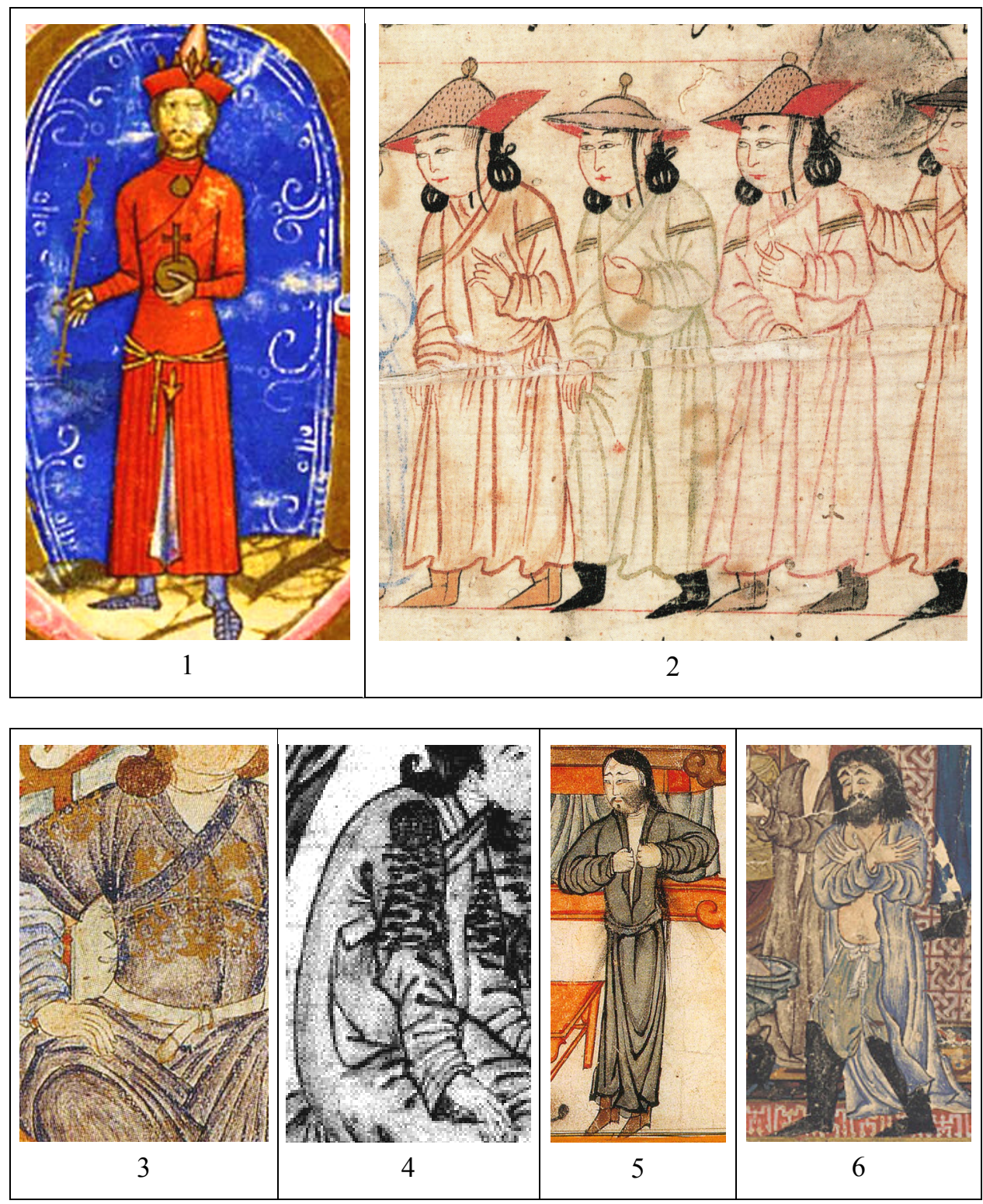

Plate 10. Variations of the male robe

(1) László Kun, from the Chronicon Pictum p. 128 (f. 64a), (2) Courtiers from the Anthology of Diwans, f. IV; The British Library, London (Manuscript 132), (3) Mongol khan from the Diez Album. Staatsbibliothek zu Berlin - Preußischer Kulturbesitz, Orientableitung, Diez A f. 70, p. 22, (4) Joseph from the Jami al-Tawarikh, f. 289a (K31), The Nasser D. Khalili Collection of Islamic Art, (5) Mourner from Diez A f. 71, p. 55, Staatsbibliothek zu Berlin - Preußischer Kulturbesitz, Orientableitung, (6) Mourner in the Great Mongol Shahnama, Freer Gallery of Art, Smithsonian Institution, Washington, D.C. (38. 3-1) 

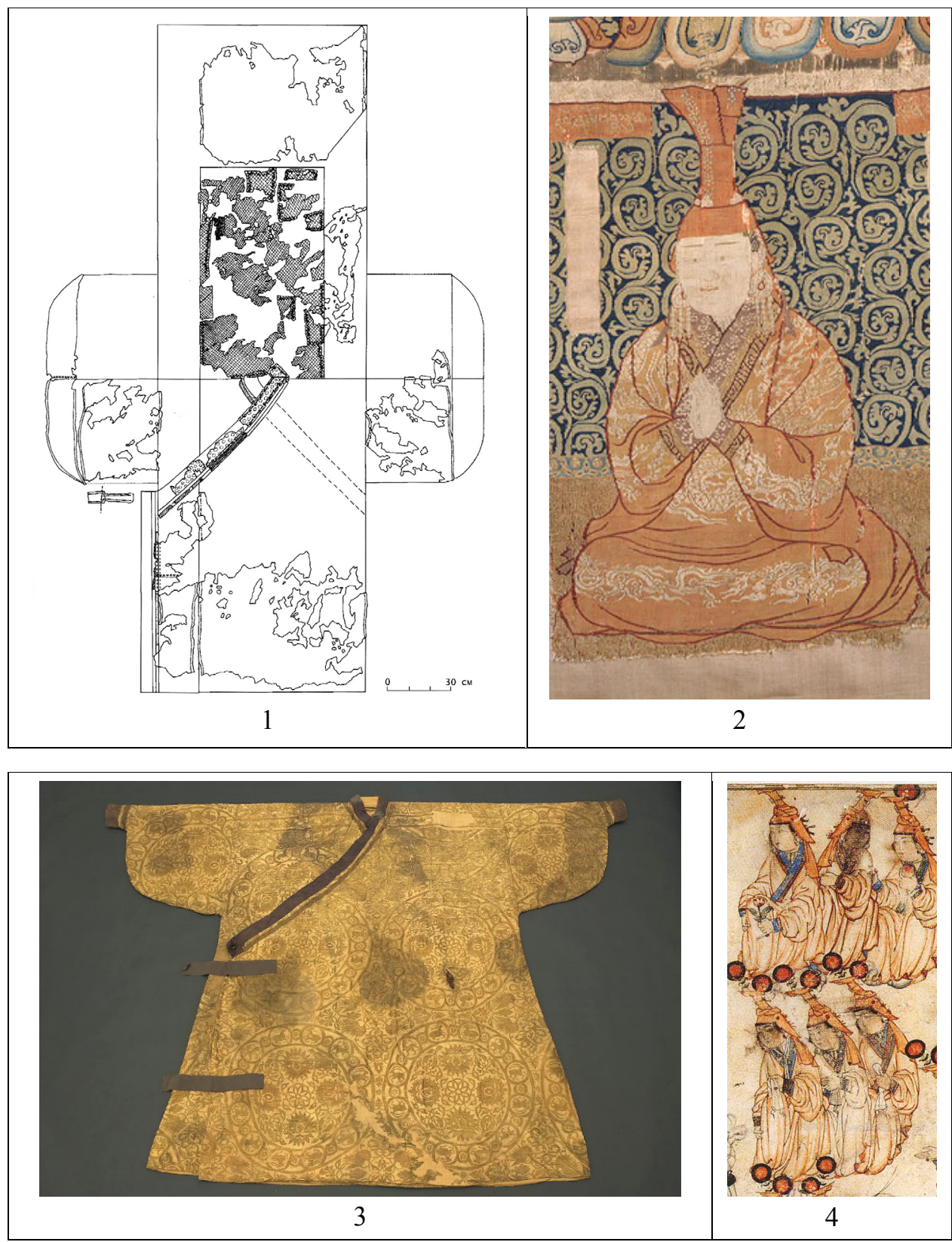

Plate 11. The female overcoat in the Great Mongol Empire

(1) The cut of the female over caftan from Verbovyj log., (2) Budashiri on the Mandala of Yamantaka-Vajrabhairava on the Metropolitan Museum of Art Purchase, Lila Acheson Wallace Gift, 1992 1992.54, (3) Mongolian woman's robe in the collection of Islamic Art, Qatar (1929321\#), (4) Ladies of the Ilkhan court from the Diez Albums. Staatsbibliothek zu Berlin - Preußischer Kulturbesitz, Orientabteilung (Diez A f. 70, p. 18, No. I) 
The No. 1 and No. 3 coats from Buxiin Xošuu, the "robe with silk braiding decoration" and the "robe with braided waist" from Inner Mongolia (Plate 10/1, /2) (Zhao Feng-Wardwell-Holborn 2004, pp. 48-53), the caftan in the David Museum's Collection etc. all have a kind of waist-decoration, which has made the Yuan costume term "bian xian ao" understandable for us. (For the different variations of the waistdecoration see Plate 9.) Before the recent archaeological discoveries, it was impossible to understand the meaning of this expression: Serruys translated it "plaited thread (into girdles) to gird their jackets" (Serruys 1957/1987, Vol. II, p. 152), Zhao Feng translates it as "breaded thread robe" while emphasising that "the waist give the effect of braided cords, without actually being braided" (Zhao Feng 2004, pp. 14, 49). ${ }^{21}$ The embroidered waist-decoration of the two coats from Buxiin Xušuu (coats No. 1 and No. 3) and their parallels certainly look like braided threads, and though they are not, this similarity explains the name (Oka 2009).

\section{Contemporary Representations of the Costumes}

\subsection{Yuan Representations of Male and Female Costumes}

"Wild goose chase" (Sheyan tu射雁图). National Palace Museum Taipei, Taiwan Inv.-Nr. guhua 000872 (Dschinggis Khan 2005, pp. 314-315, Cat. 358 Liu Fang-ju)

"Six Horses", Anonymous painter. Metropolitan Museum of Art Bequest of John M. Crawford Jr., 1988 (1989.363.5). ${ }^{22}$

Zhao Mengfu (1254-1322): Groom and Horse (Dated 1296). Metropolitan Museum of Art Gift of John M. Crawford Jr., 1988 (1988.135). ${ }^{23}$

Troupe of Actors in Performance, 1324. Minyingwang Hall, Shanxi Province (Dschinggis Khan 2005, pp. 306-307). ${ }^{24}$

Murals of the Yuan tomb at Donger, in Pucheng County, in Shaanxi (Bayar-Erdenbat 2004, pp. 208-231).

“Bu she zong fa 歩射總法” Shilin Guangji 事林廣記 (1330-1333 ed.) ${ }^{25}$ (Watt-Hearn 2010 , p. 76, figure 106, and p. 78, figure 109).

${ }^{21}$ Yuan Shi, bai guan zhi sun, dong zhi fu fan jiu deng 百官質孫、冬之服凡九等。『元 史』巻 78 、志第 28、輿服 1、1938 頁; Bian xian ao, zhi ru zhai xiu shan, yao zuo bian xian xi zhe 辮線襖、制如窄袖衫、腰作辫線細摺。

${ }^{22} \mathrm{http}: / /$ www.metmuseum.org/toah/works-of-art/1989.363.5 (Retrieved on 09.09.2015).

${ }^{23} \mathrm{http}: / /$ www.metmuseum.org/toah/works-of-art/1988.135 (Retrieved on 09.09.2015).

${ }^{24}$ Zhongguo huajing congshu bianjizu 中国画经丛书编辑组 (2006, pp. 72-73).

${ }^{25}$ The encyclopedia of popular knowledge, Shilin Guangji 事林廣記, originally compiled by Chen Yuanjing 陳元靚 during the Southern Song, but extant editions date from the Yuan and early Ming periods. 
Mongol Dancer, 13th century, Jin (1115-1234) or Yuan dynasty (1271-1368) (WattHearn 2010, p. 40, p. 54, figure 68). ${ }^{26}$

The portraits of the Yuan Empresses (Dschinggis Khan 2005, pp. 308-311, figures $349-355)^{27}$

The portraits of Yuan Empresses on the Yamantaka Mandala with imperial portraits (Watt-Wardwell 1998, pp. 95-99, p. 140, figure 69). ${ }^{28}$

These male coats have the same silhouette, the similar, long, tapering sleeves and flaring skirt. Most of them has shawl collar. Each of them has been lined, and perhaps padded, too. The side-fastening is very rarely depicted, for instance in the picture from the “Bu she zong $f a$ 歩射總法”? Shilin Guangji. In this case the coat has tiny buttons, like Coat No. 2 from Buxiin Xušuu ${ }^{29}$ (Watt-Hearn 2010, p. 76, figure 106). I do not think that more examples are necessary to prove that the coats from Buxiin Xušuu belonged to the typical clothing of the elite of the Yuan Empire, though there is no known representation of coats made completely of nasij. In the painting of the "Six Horses" (Plate 9/3) and the murals of the Yuan tomb at Donger, we can see a simpler variation of the No. 1 and No. 3 coats from Buxiin Xušuu: the coats' skirts are not plaited. In the painting of Zhao Mengfu (Table 9/5), on the murals in Minyingwang Hall, and in one picture in the “Bu she zong $f a$ 歩射總法”, in the Shilin guangji (Watt-Hearn 2010, p. 78, figure 109) instead of the embroidered waistdecoration, the coats have a long, rectangular, horizontal stripe of cloth inserted in the design of the robe, just under the narrow (leather?) belt. The pictures seem to represent the cheaper variation of the nasij coat; the textile does not look so expensive, the embroidery is missing, but the main characteristics of the cut resembles to the cut of the No. 1 and No. 3 coats from Buxiin Xušuu. When there is a waist decoration in the pictures, we cannot decide whether they are done with embroidery, or textile strings, but the tiny plaits depicted on them put these robes into the type of the coats No. 1 and No. 3 from Buxiin Xušuu. The female overcoats depicted in the portraits of the Yuan Empresses have the same characteristics as the No. 2 silk coat from Nartiin Xad; for reasons unknown, they are usually of red or pink colour (see Budashiri's portrait on Plate $11 / 2) .{ }^{30}$

26 "Mongol Dancer", dated to the Jin-Yuan dynasty lent by Henan Museum to the Metropolitan Museum of Art for the exhibition "The World of Khubilai Khan: Chinese Art in the Yuan Dynasty" September 28, 2010 - January 2, 2011 (Watt-Hearn 2010, pp. 40, 54, figure 68).

${ }^{27}$ The half-length portraits of the Yuan emperors and empresses now are in the National Palace Museum, Taipei. www.npm.gov.tw In these pictures, only the upper part of the costumes are depicted. Based on this, the type of the female overcoat can be decided but the male coats' not, that is why I did not include them.

${ }^{28}$ Yamantaka Mandala with Imperial Portraits Silk tapestry (kesi) Yuan Dynasty ca. 132 133. The Metropolitan Museum of Art, New York, Purchase, Lila Acheson Wallace Gift, 1992 (1992.54) http://www.metmuseum.org/toah/works-of-art/1992.54 (Retrieved on 09.09.2015.)

${ }^{29}$ In Liu Guandao's picture (Khubilai Khan Hunting) the black/brown fastening ribbons are partly visible on the red coat of a Southern Asian companion of the emperor. However, the coat does not belong to the types discussed in this paper (Watt-Hearn 2010, p. 77, figure 108).

${ }^{30}$ Budashiri on the Mandala of Yamantaka-Vajrabhairava on the Metropolitan Museum of Art Purchase, Lila Acheson Wallace Gift, 19921992.54 (Watt-Hearn 2010, pp. 112-113, figure 146). 


\subsection{Representations of Similar Costumes in Other Parts of the Great Mongol Empire}

\subsubsection{Ilkhanid Empire}

The next question is whether these costumes - the costumes of the Yuan - were the typical clothing of the entire Great Mongol Empire, or were they typical of and constricted to the Yuan?

The miniatures of the Ilkhanid Empire give us detailed information about the clothing of the realm (Soudavar 1996, p. 178). Abolala Soudavar's characterisation of Rostam's costume in the Edinburgh Jami al-Tawarikh ("Compendium of Chronicles") as a "Chinese-style tunic, slightly different from the robes in the Yuan dynastic portraits and seemingly fashionable at the Ilkhanid court" ${ }^{\prime 31}$ is applicable to most of the clothes in the Ikhan miniatures (Soudavar 1996, pp. 178-179) (Dschinggis Khan 2005, pp. 252-279). However, these similarities do not include the embroidered waistdecoration and the plaited skirt. The waist-decoration is not completely absent, but I know only a few representations of it: for instance, in a miniature of Kai Khusrau enthroned holding a sword, ${ }^{32}$ (Plate 9/4), a miniature of "Darab sleeping in the ruined vault", where Darab is dressed in a white robe which has a waist-decoration made of a patterned brocade, ${ }^{33}$ and the robes of "Iskandar's iron cavalry" which have perhaps a three-layered waist-decoration, which are closer to the horizontal undecorated panel of the everyday variation of the No. 2 robe from Buxiin Xušuu (Komaroff-Carboni 2002 , pp. 134, 256, figure 160). I cannot consider these waist decorations a characteristic part of the Ilkhanid costumes. It is obvious that the xian bian ao decoration was not common on Ilkhanid gowns, at least not according to the pictorial evidence. There are plenty of representations of the nasij robes in the contemporary illustrated manuscripts, especially in the Great Mongol Shahnama and the First Small Shahnama (Komaroff-Carboni 2002, pp. 150-167). In these pictures, the Ilkhanid costumes are represented consistently and share some basic characteristics which are similar to but not exactly the same as the Yuan costumes; for instance, sometimes they have standing collars, or a rounded neck-opening which continues in a diagonal shawl collar and/or trimming (Komaroff-Carboni 2002, figure 123). ${ }^{34}$

${ }^{31}$ The dying Rostam shoots Shaghad: Rashid al-Din, Jami' al-Tawarikh ('Compendium of Histories') Il-Khanid: Tabriz, 1314 Edinburgh University Library, MS. Or. 20, f. 15v.

32 "Kai Khusrau Enthroned Holding a Sword": folio from a Shahnama (Book of Kings); folio from an illustrated manuscript, Purchase, Joseph Pulitzer Bequest, 1934 Accession Number: 34.24.5 (http://www.metmuseum.org/Collections/search-the-collections/140006274) (Retrieved on 09.09.2015).

${ }^{33}$ Smithonian http www.museumsyndicate.com_images_5_44635 Edinburgh University Library, MS. Or. 20, f. 15v.

${ }^{34}$ Isfandiyar's Funeral Procession, Page from the Great Mongol Shahnama, Iran (probably Tabriz), 1330s. The Metropolitan Museum of Art, New York, Purchase, Joseph Pulitzer Bequest, 1933 (33.70). http://www.metmuseum.org/collection/the-collection-online/search? $\mathrm{ft}=\mathrm{Isfandiyar} \%$ E2\% $\% 0 \% 99 \mathrm{~s}+$ Funeral+Procession $\% 2 \mathrm{c}+$ Page + from + the + Great + Mongol+Shahnama $\% 2 \mathrm{c}+($ Retrieved on 09.09.2015). 
Again and again, the details of the male costumes indicate that different variations of a similarly-looking robe coexisted in the Mongol clothing and coats comparable to No. 4 under-caftan seem to appear in the pictures rather frequently (Dschinggis Khan 2005, pp. 253-274). The skirts of these costumes are not plaited, but when the frontal central vertical seam is clearly indicated on the upper part of them, it is usually missing under the waist, i.e. there must be a horizontal cross-partition between them (Plate 9, Plate 10/2). In other pictures, the frontal vertical seam appears in the whole length of the dress, indicating a cut similar to the Buxiin Xušuu 2 coat, but without the side-fastenings (Dschinggis Khan 2005, p. 275: pictures $303-304) .{ }^{35}$ The majority of these coats are overlapping to the right. The depictions of the side-fastenings are very rare, but not completely absent; the painters could depict them if they wanted to do so ${ }^{36}$ (Plate 10/3). The ribbons had not been functional on the Nartiin Xad No. 4 under-caftan, either; it seems that they gradually disappeared as a decorative element. The side seams are rarely indicated, but when they are, they confirm this supposition $^{37}$ (Plate 10/4).

In these pictures, the overlapping and the side seams are fairly realistically depicted; the ribbons and strings disappeared, and the cut is not always the same, but it is basically a dress which has been made to look like a "Mongol" coat, just like the Nartiin Xad No. 4 (Komaroff-Carboni 2002, p. 80, figure 84). ${ }^{38}$ In the funeral scenes, when the mourners are depicted tearing their robes apart, the difference between the Nartiin Xad No. 4 type dresses and the coats with a full frontal opening is clearly recognisable (Plate 10/5-6). The female gowns look exactly like the Yuan overcoat ${ }^{39}$ (Plate 11/4). Outside the Ilkhanid realm, we have archaeological evidence also from the Juchid realm, but only a few of them have useful figural representations. One of the latter is a stone tympanum, now in the collection of the Metropolitan Museum of Art. ${ }^{40}$ The

${ }^{35}$ Picture 303: Rustams Geburt. Staatsbibliothek zu Berlin - Preußischer Kulturbesitz, Orientabteilung Diez A f. 71, p. 11, No. 3 Picture 304: Hinrichtung. Staatsbibliothek zu Berlin - Preußischer Kulturbesitz, Orientabteilung Diez A f. 71, p. 11, No. 3.

${ }^{36}$ For instance, in the picture of $\mathrm{Zal}$ from the Great Mongol Shahname, there are three men in the same pose. The painter indicated the fastening ribbons or strings only in one case; it seems a logical assumption that he did not do so in the other cases because they were not always present on the robes. Zal approaching Shah Manuchihr, from a page of Great Mongol Shahname (Iran, probably Tabriz). The Trustees of the Chester Beatty Library, Dublin (Per 111.4) (Komaroff-Carboni 2002, p. 162, figure 189 [cat. no. 38]).

${ }^{37}$ An illustration in the 1305-1314 Jami ${ }^{\circ}$ al-Tawarikh by Rashid al-Din. Universal History or Compendium of Chronicles Ğāmic al-tavārīhn. Rašīd al-Dīn Fazl-ullāh Hamadānī Jusuf/Joseph and his brethren (Gray 1978, plate 31) and (Blair 1995, p. 82, figure 48). In Gray's study, the picture is on f. 49r, while according to Blair (1995, p. 82, figure 48), it was on f. 289 a of the reconstructed manuscript.

${ }^{38}$ Enthronement Scene, illustration from the Diez Albums, Iran (possibly Tabriz), early 14th century Staatsbibliothek zu Berlin - Preußischer Kulturbesitz, Orientabteilung (Diez A f. 70, p. 22); for other Ilkhanid examples, see Komaroff-Carboni (2002 passim) and Gray (1978).

${ }^{39}$ Ladies of the Ilkhan court from the Diez Albums. Staatsbibliothek zu Berlin - Preußischer Kulturbesitz, Orientabteilung (Diez A f. 70, p. 10) (Dschinggis Khan 2005, p. 258, figure 286).

${ }^{40}$ Tympanum, late 14th-early 15th century; Golden Horde, Daghestan region, Caucasus (probably Kubachi). Carved stone with traces of paint (38.96), http://www.metmuseum.org/toah/ 
rider on this relief wears a coat similar to the No. 1 coat from Buxiin Xušuu, with a cloud-collar, waist-decoration and appliques on the hem of the coat.

The representations of similar costumes are not restricted to the territory of the Great Mongol Empire. A few times they appear in contemporary Italian paintings on "foreigners" whose identity is no concern of this article. In one picture, Ambrogio Lorenzetti's fresco, "The Martyrdom of the Franciscans", 41 the robes of the soldiers in the background resemble the costumes in the Ilkhanid miniatures (see Representations of Similar Costumes in the Other Parts of the Great Mongol Empire, Ilkhanid Empire in this paper). We have another kind of representations in Hungary in a completely different context. In the miniatures of the Chronicon Pictum Vindobonense ancient Huns, ancient and contemporary Hungarians, Cumans, Pechenegs, Mongols, Ruthenians, Valachians, and even an envoy of the Byzantine Emperor appear wearing different types of Oriental clothing; one type seems fairly close to the No. 4 undercaftan from Nartiin Xad (Plate 10/1). These gowns have long, narrow sleeves, a closefitting upper part, an overlapping to the right or to the left, a horizontal cross-partition, a central vertical seam on the back (though not on the front) and comparatively wide plaits on their long skirt. They are not exactly like the archaeological finds from Buxiin Xušuu; actually, they are showing some characteristics of the Ilkhanid clothing, too; for instance, sometimes they have a rounded neck-opening which continues in a diagonal shawl collar and/or trimming, etc. ${ }^{42}$ Also the typology and complete costume history of the manuscripts are much more complicated, and these gowns form only one type of the clothing. I mention only those pictures of the Chronicon Pictum Vindobonense where the costumes have all the above-mentioned characteristics: p. 7 (f. $4^{\mathrm{a}}$ ), p. 9 (f. 5), p. 11 (f. $6^{\text {a }}$ ), 60 (f. $30^{\text {,a }}$ ), p. 13 (f. $7^{\text {b }), ~ p . ~} 21$ (f. 11), p. 32 (f. 16'), p. 60 (f. $30^{\text {a a }}$ ), p. 72 (f. $36^{\text {,a }}$ ), p. $78\left(39^{\text {,a }}\right.$ ), p. 98 (f. 49,a), p. 121 (f.?), p. 125 (f. 63), p. 128 (f. $64^{\text {, b }}$ ) and p. 129 (f. $65^{\text {b }}$ ). ${ }^{43}$ The bian xian ao decoration is not represented in the miniatures, but sometimes a plain two-layered, undecorated central panel appears on the waist, between the plaited skirt and the upper part of the gown. It resembles the Yuan male-caftans with the undecorated "under-belt" panels (Plate 9/5-6).

After the new archaeological discoveries from the Jochid Realm, we know that at least some of the representations of the gowns in these pictures can be accepted as

works-of-art/38.96 (Retrieved on 09.09.2015). The Metropolitan Museum of Art Bulletin, New Series, Vol. 33, No. 1, Islamic Art (Spring, 1975), pp. 2-52.

${ }^{41}$ Ambrogio Lorenzetti (Siena, about 1290-Siena, 1348), Martyrdom of the Franciscans 1336-1340, Church of San Francesco, Siena, Italy: http://www.gettyimages.co.jp/detail/the-martyr dom-of-the-franciscans-by-lorenzetti-ambrogio-AF/115624876; http://www.gettyimages.co.jp/detail/ the-martyrdom-of-the-franciscans-by-lorenzetti-ambrogio-AF/1156248767; http://www.wikigallery. org/wiki/painting_343440/Ambrogio-Lorenzetti/Martyrdom-of-the-Franciscans (All of these webpages were retrieved on 09.09.2015.)

${ }^{42}$ See footnote 30 .

${ }^{43}$ See Kepeskronika.net Dercsényi-Gárdonyi (1964). Of course as we have only the front, or the back or the side view of a robe, and because there are so many close variations of this type, sometimes we cannot be sure that all of the above-mentioned characteristics exist together on each costume. 
realistic, or at least attempts to represent real clothes. Of course, in the lack of archaeological textiles from the Carpathian basin, this supposition cannot yet be proved.

\section{Conclusion}

This research was based on the recent archaeological textile finds from Buxiin Xušuu and Nartiin Xad in Mongolia. In these cave burials, a man and a woman were buried, and among their otherwise unexceptional grave-goods, several costumes had been found in very good state of preservation. According to the excavating archaeologists these cave burials belonged to the elite of the Yuan era. It is not surprising then that the closest parallels of the robes can be found in the territory of the Yuan, and they are depicted in the figural representations of Yuan art. Comparing them to the archaeological finds and artistic representations of the Great Mongol Empire, a more complex picture emerges. There is no such thing as a uniform Mongol costume; rather, several types existed side by side. Even a single grave (at Buxiin Xušuu) contains three coats which are different in their cut and decoration, though their similar silhouette and waist-decoration make them recognisably "Mongol", moreover, Yuan costumes, because the embroidered waist-decoration was not popular outside the Yuan Empire. In the Ilkhanid miniatures, the male costumes seem to be closer to the Nartiin Xad under-caftan, i.e. they were not coats, but dresses, and the majority of the female overcoats look just like the Nartiin Xad No. 2 coat. In the Jochid Realm, we do not have enough evidence to define the complete picture of their clothing, but archaeological material proves that the female gowns were very similar to their Yuan counterparts. We know less about the male costumes; there is a possibility that it was closer to the Yuan than to the Ilkhanid clothes, i.e. the waist decoration was maintained. In spite of the differences, these various clothes retained some similar features, for instance, their silhouette, which made each of these clothes recognisably "Mongol". Moreover, naturally enough, the clothing of the Great Mongol Empire influenced the clothing of the neighbouring territories, and costumes similar to the Ilkhanid and Jochid costumes, i.e. the variants of the Nartiin Xad No. 4 under-caftan, appear in the contemporary representations as the "typical" clothing of the Cumans, Ruthenians, etc. The costumes, which identified their owners as members of the "Mongol" elite inside the empire, got a completely different meaning outside it. The costumes of the Yuan simply became an important factor in the costume history of 13th-14th-century Eurasia.

\section{Bibliography}

Allsen, T. T. (2001): Culture and Conquest in Mongol Eurasia. Cambridge, Cambridge University Press (first edition: 1997).

Allsen, T. T. (2002): Commodity and Exchange in the Mongol Empire: A Cultural History of Islamic Textiles. Cambridge, Cambridge University Press (Cambridge Studies in Islamic Civilization).

Amitai-Preiss, R. - Morgan, D. (1998): The Mongol Empire and Its Legacy. Leiden, Brill (Islamic History and Civilization). 
Baiarsaikhan, J. (2009): A 13-14th Century Mongolian Grave at Bukhiin Khoshuu. In: Current Archaeological Research in Mongolia: Papers from the First International Conference on 'Archaeological Research in Mongolia', held in Ulaanbaatar, August 19th-23th, 2007. Bonn, Vor- und Frühgeschichtliche Archäologie Rheinischen Friedrich-Wilhelms-Universität (Bonn Contributions to Asian Archaeology, Volume 4), pp. 477-486.

Bayar, D. - Erdenbat, U. (2004): Dundad zuunii mongolcuud bunxanii xaniin zuragt. Studia archaeologica (Ulaanbaatar) Vol. 22, No. 18, pp. 208-231.

Beazley, C. R. (ed.) (1903): The Texts and Versions of John de Plano Carpini and William de Rubruquis, as Printed for the First Time by Hakluyt in 1598, together with Some Shorter Pieces. London, Hakluyt Society.

Bemmann, J. (ed.) (2012): Steppenkrieger: Reiternomaden des 7.-14. Jahrhunderts aus der Mongolei. Bonn, Primus Verlag GmbH.

Berend, N. (2001): Cuman Integration in Hungary. In: Khazanov, A. N. - Wink, A. (eds): Nomads in the Sedentary World. Richmond, Curzon Press, pp. 103-127.

Blair, S. (1995): A Compendium of Chronicles: Rashid al-Din's Illustrated History of the World. London, The Nour Foundation (The Nasser D. Khalili Collection of Islamic Art, Vol. XXVII).

Dercsényi, D. - Gárdonyi, K. (eds) (1964): Képes Krónika. - Chronicon Pictum, I-II. Budapest, Magyar Helikon.

di Cosmo, N. - Frank, A. J. - Golden, P. B. (eds) (2009): The Cambridge History of Inner Asia: The Chinggisid Age. Cambridge, Cambridge University Press,

Dinwiddie, D. - Zhao Feng - Holborn, M. - Wardwell, A. E. (2004): Style from the Steppes: Silk Costumes and Textiles from the Liao and Yuan Periods, 10th to 13th Centuries. Exhibition Catalogue. London, Anna Maria Rossi and Fabio Rossi Publications.

Dschinggis Khan (2005): Dschinggis Khan und seine Erben. Das Weltreich der Mongolen. Exhibition Catalogue. Kunst- und Ausstellungshalle der Bundesrepublik Deutschland. München, Hirmer Verlag.

Erdenbat, U. - Amartüwšin, Ts. (2010): Dugui Caxiryn xadny oršsulga (X-XII. juun). Ulaanbaatar, Bembi San.

Erdenbat, U.-Xürelsüx, S. (2007): Nartyn xadny oršuulga. Studia Archaeologica Tomus (IV) XXIV, Fasc. 23, pp. 332-359.

Fletcher, J. F. - Forbes Manz, B. (1995): Studies on Chinese and Islamic Inner Asia. Aldershot, Hampshire, Brookfield, Ashgate Variorum (Collecttapstudies).

Garrett, V. M. (1994): Chinese Clothing: An Illustrated Guide. Hong Kong-Oxford-New York, Oxford University Press.

Gray, B. (1978): The 'World History' of Rashid al-Din. A Study of the Royal Asiatic Society Manuscript. London-Boston, Faber\&Faber.

Györffy, Gy. (ed.) (1965): Napkelet felfedezése: Julianus, Plano Carpini és Rubruk útijelentései [Discovery of the Orient. Travel accounts of Julianus, Plano Carpini and Rubruk]. Budapest, Gondolat Kiadó (Nemzeti Könyvtár, Művelödéstörténet).

Jackson, P. (2009): The Mongol Age in Eastern Asia. In: di Cosmo-Frank-Golden (2009), pp. $26-45$.

Kadoi, Y. (2009): Islamic Chinoiserie: The Art of Mongol Iran. Edinburgh, Edinburgh University Press (Edinburgh Studies in Islamic Art).

Komaroff, L. - Carboni, S. (eds) (2002): The Legacy of Genghis Khan. Courtly Art and Culture in Western Asia, 1256-1353. The Metropolitan Museum of Art, New York-New HavenLondon, Yale University Press.

Kuhn, D. - Zhao Feng (eds) (2012): Chinese Silks. New Haven \& London, Yale University PressBeijing, Foreign Languages Press. 
Lantratova, O. B. - Golikov, V. P.-Orfinskaja, O. V. - Vladimirova, O. F. - Jegorov, V. L. (2002): Issledovanie unikal'nih arheologicheskih pamjatnikov iz sobranija gosudarstvennogo istoricheskogo muzeja - kompleksov odezhd XIII-XIV vv. Moscow, Gosudarstvennyj Istoricheskij muzej. Otdel nauchnoj restavracii. Centr istoricheskih i tradicionnyh tehnologij. Rossijskogo nauchno-issledovatel'skogo Instituta kul'turnogo i prirodnogo nasledija.

Lxagvasüren, X. (2007): Mongoliin arhjeologi (Cinges hanii üje). Tergün dewter. Ulanbatar, Sorxon cagan HHK.

Marosi, E. (ed.) (1987): Magyarországi müvészet 1300-1470 körül [Arts in Hungary in ca. 13001470]. Vols I-II. Budapest, Akadémiai Kiadó.

Marosi, E. (1995): Képmás és hasonmás. Müvészet és valóság a 14-15. századi Magyarországon [Image and counterpart. Art and reality in 14th-15th-century Hungary]. Budapest, Akadémiai Kiadó.

Marosi, E. (1996): Magyarok középkori ábrázolásai és az orientalizmus a középkori művészetben [Mediaeval representations of Hungarians and orientalism in mediaeval art]. Néprajzi Értesitö. Annales Musei Ethnographiae Vol. 77, pp. 77-97.

Meng Ssu-ming 蒙思明 (1967): Yuan-tai she-hui chieh-chi chih-tu 元代社会階級制度. Hong Kong, Lung-men shu-tien.

Morgan, D. (2007): The Mongols. Oxford, Blackwell Publishing. (First edition: 1986.)

Oka, I. H. (2007): Cultural Interaction between Asian and European Clothing: New Textile Finds from the Great Mongol Empire. Abstract in: The 16th conference of The European Association for Archaeologists, Riva del Garda, Italy, September 2009. Unpublished.

Oka, I. H. (2009): Three Mongolian Coats from the 13th-14th Century Grave at Bukhiin Khoshuu. In: Bemann, J. et al. (eds): Current Archaeological Research in Mongolia: Papers from the First International Conference on "Archaeological Research in Mongolia" held in Ulaanbaatar, August 19th-23rd, 2007 (Bonn Contributions to Asian Archaeology, Volume 4), pp. 487-503.

Oka, I. H. (2011): Yuan Era Clothing; The Questions of Identity. Abstract. In: Abstracts of the 17th Annual Meeting of the European Association of Archaeologists, 14th-18th September 2011. Oslo-Norway.

Orfinskaja, O. V.-Lantratova, O. B. (2011a): Zhenskij kostjum zolotoordynskogo vremeni iz pogrebenija No. 93 mogil'nika Majachnyj bugor I (Astrahanskaja obl.). In: Problemy atribucii pamjatnikov dekorativno-prikladnogo iskusstva. (Materialy I nauchno-prakticheskoj konferencii 13-16 oktjabrja 2009 g. chast' I). Posvjashchaetsja pamjati T. S. Aljoshinoj / Gosudarstvennyj Istoricheskij muzej. Moscow, pp. 20-40.

Orfinskaja, O. - Lantratova, O. (2011b): Female Costume of the Golden Horde Period from Burial 93 from the Majačnyj Bugor I Cemetery of the Astrakhan Region of Russia. Archaeological Textiles Newsletter No. 52, Spring, pp. 48-63.

Pálóczi Horváth, A. (1994): Hagyományok, kapcsolatok és hatások a kunok régészeti kultúrájában [Traditions, connections and influences in the archaeological culture of the Cumans]. Karcag, Karcag Város Önkormányzata (Keleti örökségünk 2.).

Rossabi, M. (1994): The Reign of Khubilai Khan. In: Twitchett-Frank-Fairbank (1994), pp. 414 489.

Rossabi, M. (2011): The Mongols and Global History. New York-London, W. W. Norton \& Company (Norton Documentary Reader).

Serruys, H. (1957/1987): Remains of Mongol Customs in China during the Early Ming Period. Monumenta Serica 16, pp. 137-190. In: Aubin, F. (ed.) (1987): The Mongols and Ming China: Customs and History. London, Variorum Reprints. 
Soudavar, A. (1996): The Saga of Abu-Sa'id Bahador Khan. In: Raby, J. - Fitzherbert, T. (eds): The Court of the Ilkhans 1290-1340 (Oxford Studies of Islamic Art XII), pp. 95-195.

Twitchett, D. C.-Franke, D. C.-Fairbank, J. K. (eds) (1994): The Cambridge History of China: Volume 6, Alien Regimes and Border States, 710-1368. Cambridge-New York-Victoria, Cambridge University Press.

Vásáry, I. (2009): The Jochid Realm: the Western Steppe and Eastern Europe. In: di CosmoFrank-Golden (2009), pp. 67-88.

Vlaskin, M. V.-Garmashov, A. I. - Dode, Z. V.-Naumenko, S. A. (2006): Pogrebenie znati zolotoordynskogo vremeni v mezhdurech'e Dona i Sala. In: Materialy po izucheniju istoriko-kul'turnogo nasledija Severnogo Kavkaza. Vypusk VI. Moscow, Pamjatniki istoricheskoj mysli.

Vollmer, J. E. (2002): Ruling from the Dragon Throne. Costume of the Qing Dynasty (1644-1911). Berkeley-Toronto, Ten Speed Press.

Watt, J. C. Y.-Hearn, M. K. (2010): The World of Khubilai Khan: Chinese Art in the Yuan Dynasty. New York-New Haven-London, Metropolitan Museum of Art, Yale University Press.

Watt, J. C. Y. - Wardwell, A. E. (1998): When Silk Was Gold: Central Asian and Chinese Textiles. New York, The Metropolitan Museum of Art in cooperation with the Cleveland Museum of Art.

Yule, H. - Cordier, H. (eds) (1920): The Book of Ser Marco Polo, 2 vols. London.

Zhao Feng 赵丰 (2006): Meng Yuan long pao de lei xing ji di wei 蒙元龙袍的类型及地位. Wenwu No. 8, pp. 85-96.

Zhao Feng - Wardwell, A. E. - Holborn, M. (2004): Style from the Steppes: Silk Costumes and Textiles from the Liao and Yuan Periods, 10th to 13th Centuries. London, Anna Maria Rossi and Fabio Rossi Pub.

Zhongguo huajing congshu bianjizu 中国画经丛书编辑组 (2006): Zhongguo Renwu Huajingdian. Yuandai juan 中国人物画经典 元代卷 [Masterworks of Chinese figure painting Yuan Dynasty (AD 1271-1368)]. Beijing, Wenwu Chubanshe.

Zichy, I. (1934): A Képes Krónika miniatürjei viselettörténeti szempontból [Miniatures of the Chronicon Pictum Vindobonense as monuments of the history of clothing]. In: Petrovits Elek Emlékkönyv. Budapest, pp. 19-60.

\section{Online Sources (retrieved on 09.09.2015)}

Aga Khan Museum Home: https://www.agakhanmuseum.org/

Art Project: https://www.google.com/culturalinstitute/project/art-project

Google Cultural Institute: https://www.google.com/culturalinstitute/home

Internet Archive: https://archive.org/index.php

The Metropolitan Museum of Art: http://www.metmuseum.org/

Project Gutenberg: https://www.gutenberg.org/, http://www.gutenberg.org/wiki/Main_Page

Silk Road Seattle: http://depts.washington.edu/silkroad/texts/rubruck.html\#introduction http://depts.washington.edu/silkroad/texts/rubruck.html\#clothing

WikiGallery.org: http://www.wikigallery.org/wiki/Main_Page 